\title{
UPAYA MENINGKATKAN PERKEMBANGAN MORAL ANAK USIA DINI MELALUI MENDONGENG DI TK DHARMAWANITA
}

\author{
Rakihmawati \& Yusmiatinengsih \\ e-mail : rakihmawati10@yahoo.com \\ PGPAUD Universitas Negeri Padang
}

\begin{abstract}
Abstrak: Perkembangan moral anak di TK Dharmawanita UNP Padang masih sangat rendah, hal ini masih terlihat masih banyak anak-anak yang kurang memahami perbuatan baik dan buruk dari perbuatannya, seperti anak masih suka menganggu teman, kurang mempunyai rasa empati dan tidak senang bermain dengan temannya serta tidak terbiasa mengucapkan terima kasih. Salah satu penyebabnya adalah upaya guru menanamkan moral dan metode yang digunakan kurang tepat. Tujuan penelitian adalah melakukan perbaikan terhadap cara guru dalam memberikan penanaman moral melalui cerita-cerita dongeng yang mendidik dan menyenangkan. Penelitian ini adalah Penelitian Tindakan Kelas (Classroom Action Research) yaitu suatu penelitian yang meningkatkan mutu pembelajaran. Data penelitian diperoleh melalui observasi dan wawancara. Penelitian tindakan kelas ini dilakukan dalam dua siklus. Hasil penelitian setiap siklus telah menunjukkan adanya peningkatan tentang perkembangan moral anak, pada siklus I perkembangan moral anak masih banyak yang rendah, setelah dilakukan tindakan pada siklus II terjadi peningkatan. Berdasarkan hasil tindakan yang telah dilakukan dinyatakan bahwa terjadinya peningkatan perkembangan moral anak, ini terlihat sebelum tindakan pada kondisi awal persentase kemampuan anak sangat tinggi $13.23 \%$, pada siklus I naik menjadi $36.76 \%$, sedangkan pada siklus II naik menjadi $77.44 \%$. Hal ini menunjukkan bahwa perkembangan moral anak mengalami peningkatan dari sebelum tindakan sampai dilakukan siklus II. Jadi bisa disimpulkan bahwa kegiatan mendongeng dapat meningkatkan perkembangan moral anak. Penulis menyarankan kepada pembaca agar skripsi ini dapat digunakan sebagai sumber ilmu pengetahuan guna menambah wawasan dalam meningkatkan perkembangan moral anak.
\end{abstract}

Kata-kata kunci: perkembangan moral, pelajaran moral, mendongeng.

\section{IMPROVING THE MORAL DEVELOPMENT OF EARLY AGE CHILDREN THROUGH JOYFUL FABLES}

\begin{abstract}
The moral development of children at Dharmawanita kindergarten in Padang State University is still low, it seems that there are still children with less understanding of good and bad attitude from their behaviors, like disturbing children, less emphaty feeling and unhappy to play with their friends, and also unused to say thank. One of the causes are the teacher's effort to grow morale and incorrect method in teaching it. The purpose of this research is to fix the teacher's ways in growing morale lesson through educated and joyful fables. This research is the classroom action research, the research which increases the learning quality. The research data done by observation and interview. The classroom action research done in two cycluses. The result of this research had shown that there is the increase of children morale development, in cyclus 1, the moral development of children was still low, after cyclus II had been done, there was increasement. Based on the classroom action research, there was an increase of children morale development, it seemed before the action in the early percentage of children ability which was very high $13,23 \%$, in cyclus I it got increased into 36, $76 \%$, meanwhile in cyclus II, it got great increased into $77.44 \%$. it shows that there is an increasement of children morale development from the early action before cyclus till cyclus II. The conclusion is telling fable can increase the children morale development. The writer suggests to the readers that this thesis can be used as the source to explore the knowledge increasing the children morale development.
\end{abstract}

Keywords: moral development, moral lesson, joyful fable

\section{PENDAHULUAN}

Pendidikan merupakan suatu hal yang sangat penting bagi setiap generasi bangsa. Pendidikan dan proses pembelajaran diharapkan dimulai sejak dini.
Upaya mencerdaskan bangsa melalui sistem pendidikan nasional tercantum dalam UU Republik Indonesia Bab II pasal 3 menyatakan sebagai berikut: Pendidikan 
nasional berfungsi mengembangkan potensi peserta didik agar menjadi manusia yang beriman, berakhlak mulia, sehat, berilmu, kreatif, serta bertanggung jawab.

Pendidikan anak usia dini diselenggarakan sebagai upaya meletakkan dasar-dasar perkembangan sebelum memasuki pendidikan dasar. PAUD di Indonesia dimulai sejak anak berusia 0-6 tahun. TK merupakan dasar pendidikan yang pertama dimasuki anak selain keluarga, upaya TK adalah untuk mencerdaskan dan meningkatkan kualitas anak-anak Indonesia. Pendidikan yang benar dengan formulasinya yang diperuntukkan bagi peserta didik semenjak usia dini akan memberikan efek positif bagi perkembangan anak itu sendiri.

TK merupakan salah satu pendidikan anak usia dini mulai dari usia 5-6 tahun, yang mengembangkan seluruh aspek pengembangan yang ada pada diri anak. Aspek yang ada pada diri anak meliputi aspek perilaku, kognitif, fisik motorik, bahasa dan seni. Setiap aspek harus dapat dikembangkan dengan baik dan sesuai dengan tahap-tahap perkembangan usia anak. Seluruh aspek dapat dikembangkan dengan baik tentu dibutuhkan seorang guru yang profesional.

Guru sebagai pembelajar dalam pelaksanaan proses pendidikan ini harus mengerti secara baik dan benar teknik serta praktik pembelajaran sesuai dengan perkembangan usia peserta didik itu sendiri, sebab kesalahan dalam proses akan melahirkan kefatalan dalam hasil. Guru tidak hanya berpedoman kepada kurikulum tetapi juga harus menguasai berbagai macam teori dengan memanfaatkan berbagai media demi keefektifan dalam proses belajar dan mengajar.

TK mempunyai prinsip bermain sambil belajar dan belajar seraya bermain. Bermain adalah kegiatan yang menyenangkan dan melalui kegiatan yang menyenangkan akan dapat mengembangkan seluruh aspek pengembangan pada anak salah satunya perkembangan moral.

Dalam perkembangan moral, anak usia dini masih banyak belajar tentang berbagai hal dalam kehidupannya. Anak belajar mengamati, mengenal, dan berbuat sesuai kata hati mereka. Anak belajar berbagai peristiwa dalam hidupnya dan dari berbagai peristiwa tersebut anak akan menerima pengaruh positif dan negatif serta sifat empati dari diri anak terhadap orang lain juga berkembang jika anak dapat bimbingan dan pengarahan dari orang dewasa. Untuk itulah dibutuhkan bimbingan dan arahan sejak usia dini agar perilaku baik ini tetap tertanam hingga dewasa.

Namun harapan di atas sangat berbeda dengan kenyataan yang penulis temui di lapangan. Anak juga sering mengganggu teman dalam bermain dan belajar dan tidak peduli dengan kesusahan orang lain dan lebih mementingkan dirinya sendiri.

Fenomena seperti inilah yang sering penulis temui di TK Dharmawanita UNP Padang karena masih banyak anak didik yang masih belum memahami baik atau buruk dari perbuatan yang dilakukan. Hal ini dapat dilihat dari sikap dan kebiasaan anak sehari-hari di sekolah seperti mengganggu teman dalam belajar dan bermain, tidak suka menolong, belum terbiasa mengucapkan terima kasih dan tidak mau saling memaafkan jika melakukan kesalahan.

Guru mempunyai peranan yang penting dalam memberikan pengarahan dan penjelasan kepada anak tentang sikap perilaku yang baik dan buruk serta akibat dari perbuatan dengan cara yang menyenangkan, contohnya pada proses pembelajaran berlangsung maupun saat anak bermain anak suka merebut mainan temannya, menertawakan teman yang terjatuh, tidak mau berbagi dan tidak terbiasa berterima kasih jika mendapatkan sesuatu, hal ini sering luput dari perhatian guru. Dalam proses pembelajaran guru lebih suka mengajarkan membaca, menulis, mewarnai gambar daripada memberikan bimbingan dan arahan terhadap sikap perilaku sehari-hari.

Dongeng memiliki peran mengubah etika anakanak. Dongeng merupakan cara untuk mendidik anak sejak dini. Tidak hanya orang tua yang memilih jalan untuk mendongeng dalam mendidik anak, tetapi juga guru. Namun ketika mendongeng, guru membutuhkan trik-trik khusus, dan kreatif untuk menarik perhatian murid - muridnya agar suasana menjadi lebih hidup.

Oleh sebab itu penulis tertarik untuk meneliti "Upaya Meningkatkan Perkembangan Moral Anak Usia Dini melalui Mendongeng di TK Dharmawanita UNP Padang". Penulis mengharapkan dengan mendongeng ini akan dapat memberikan suatu pembaharuan kepada guru TK dalam memberikan penanaman moral kepada anak dengan cara yang menyenangkan.

Penulis menemukan penyebab timbulnya masalah tersebut, yaitu (1) masih kurangnya pemahaman anak tentang perilaku baik dan buruk; (2) kurangnya ketertarikan anak dalam mendengar cerita; (3) kurang perhatian guru terhadap tingkah laku anak sehari-hari di sekolah; dan (4) kurang kegiatan mendongeng dalam memberikan penanaman nilai moral kepada anak.

Penulis membatasi masalah dalam hal kurangnya pemahaman anak tentang perilaku baik dan buruk di TK Dharmawanita UNP Padang sehingga menimbulkan pertanyaan "Apakah melalui mendongeng akan dapat meningkatkan perkembangan moral anak di TK Dharmawanita UNP Padang?". 
Penelitian ini bertujuan melakukan perbaikan terhadap cara guru dalam memberikan penanaman moral melalui cerita-cerita dongeng yang mendidik dan menyenangkan. Tentunya, penelitian ini memiliki manfaat baik bagi anak, orang tua, guru, sekolah, maupun pendidikan bagi anak usia dini.

1. Bagi anak; penelitian ini bermanfaat untuk memberikan penanaman moral dengan cara yang menyenangkan.

2. Bagi orang tua; penelitian ini bermanfaat bagi orang tua sebagai motivasi untuk memberikan bimbingan dan arahan kepada anak.

3. Bagi guru; penelitian ini bermanfaat bagi guru dalam mengetahui bagaimana teknik mendongeng yang baik

4. Bagi sekolah; penelitian ini bermanfaat bagi sekolah sebagai perbaikan terhadap strategi pembelajaran di TK

5. Bagi Pendidikan Anak Usia Dini; penelitian ini bermanfaat bagi Pendidikan Anak Usia Dini sebagai masukan agar dapat memberikan kegiatan mendongeng yang menyenangkan bagi anak.

\section{Kajian Teoretis}

\section{Hakikat Moral}

Menurut Hurlock (1997: 74) mengemukakan bahwa kata moral berasal dari mores (bahasa latin) yang berarti tata cara kebiasaan atau adat istiadat. Dalam kehidupan perilaku moral berarti perilaku yang sesuai dengan kode moral kelompok sosial, perilaku moral dikendalikan konsep-konsep moral peraturan perilaku yang menjadi kebiasaan bagi anggota suatu budaya.

Prent dalam Hermansyah (2000: 3) mengatakan perkataan moral berasal dari suku kata "mos" yang berarti (tunggal) sedangkan Mores (Jamak) diartikan sebagai adat istiadat, kelakuan, tabiat, watak, dan akhlak. Dari pendapat para ahli dapat disimpulkan bahwa moral adalah sikap perilaku atau perbuatan seseorang yang bertindak sesuai dengan adat istiadat atau kebiasaan anggota suatu budaya.

Perkembangan moral pada anak dapat dilihat dari sikap dan perilaku sehari-hari, anak dapat membedakan suatu perbuatan yang dilakukan itu baik atau buruk. Santrock (2007: 117) menyatakan bahwa "perkembangan moral adalah perubahan, penalaran, perasaan, dan perilaku tentang standar mengenai benar dan salah".

Musfiroh (2005: 14) mengatakan perkembangan moral anak berlangsung secara berangsur-angsur tahap demi tahap. Terdapat tiga tahap dalam pertumbuhan ini: tahap amoral (anak tidak mempunyai rasa benar atau salah), tahap konvesial (anak menerima nilai-nilai dan norma dari orang tua dan masyarakat), serta tahap otonomi (anak membuat pilihan sendiri secara bebas).

Perkembangan moral mempunyai aspek kecerdasan dan aspek implusif anak harus belajar apa saja yang benar dan salah, selanjutnya segera setelah cukup besar harus diberi penjelasan mengapa itu benar dan salah. Perkembangan moral anak dapat dipengaruhi oleh perkembangan intelektual dan penalaran, oleh karena itu diperlukan latihan bagi anak tentang bagaimana berperilaku moral dan konteks tertentu.

Dari penjelasan di atas dapat disimpulkan bahwa perkembangan moral adalah tindakan atau perbuatan seseorang tentang yang salah atau benar dan baik atau buruk untuk bertindak sesuai dengan kebiasaan anggota suatu budaya. Untuk itu perlu diberikan arahan dan bimbingan kepada anak agar dapat membedakan perbuatan yang dilakukan baik atau buruknya.

Perilaku buruk pada anak usia dini lebih mengarah kepada perilaku amoral. Beberapa di antara prilaku buruk anak kecil lebih bersifat amoral daripada tak bermoral. Sifat amoral anak lebih banyak mengarah kepada perilaku buruknya.

Gichara (2006: 21) mengatakan perilaku buruk adalah suatu kondisi terhambatnya pemenuhan kebutuhan seseorang atau frustasi serta perasaan terancam yang disebabkan oleh beberapa faktor (1) emosi yang tidak terkendali; (2) lingkungan sosial yang tidak mendukung; (3) penanaman disiplin yang keliru; (4) tekanan di sekolah, kompetensi, standar moral; dan (5) tidak cukup gizi.

Berikut bentuk perilaku buruk pada anak usia dini menurut Gichara: (1) berkelahi (memukul, mendorong, dan menggoda). Tindakan memukul, mendorong, berkelahi, dan menggoda sering dianggap normal. Padahal, hal itu bisa membuat anak bertindak kasar pada anak lain sehingga menimbulkan perkelahian. (2) Mengamuk dan marah-marah. Anak kecilpun bisa mengamuk karena merasa terganggu atau ada sesuatu yang mengganjal di dalam hatinya. (3) Menggigit. Tindakan menggigit umumnya dilakukan oleh anakanak. Menggigit merupakan perilaku agresif yang tidak disengaja. (4) Berbohong. Kebanyakan anak berbohong karena takut mendapat hukuman. (5) Berbicara kasar atau mengucapkan kata-kata kotor. Kata-kata kasar biasanya timbul bila anak disakiti, diganggu, atau kebutuhannya tidak terpenuhi. (6) Mengejek. Kadangkadang tindakan mengejek juga timbul karena sekedar iseng dan hanya ingin menggoda temannya. (7) Mengadu. Biasanya terjadi bila salah seorang anak tidak mampu memberikan perlawanan terhadap orang yang 
menguasai atau memberi perlawanan kepadanya. (8) Mencuri. Anak melakukannya bukan karena ingin menyusahkan orang lain melainkan karena masih berorientasi pada diri sendiri dan belum bisa menahan dorongan hatinya.

Agus D.S (2009: 56) mengatakan untuk mengajarkan anak dan memberikan pemahaman tentang moral pada anak memang bukan hal yang mudah walaupun bukan lagi hal yang tabu. Hanya saja masalah ini masih merupakan hal yang sulit bagi anak-anak untuk memahami kata-kata mengenai kejujuran, kesetiakawanan, sopan santun, empati, dan segala yang menyangkut soal moral.

Dari penjelasan di atas dapat dijelaskan bahwa perilaku buruk anak lebih mengarah kepada tindakan amoral, untuk itu lebih dibutuhkan arahan dan bimbingan supaya amoral ini menjadi moral. Hal ini harus menjadi perhatian bagi guru dan orang tua dalam mendidik anak supaya menjadi orang yang berbudi pekerti luhur.

\section{Pentingnya Penanaman Moral Kepada Anak Usia} Dini

Usia kanak-kanak adalah usia yang sangat penting untuk dilakukan penanaman nilai moral. Pada usia prasekolah (di bawah enam tahun) aspek emosi dan kognitif anak masih dalam masa perkembangan. Kedua aspek emosi tersebut baru terbentuk secara matang ketika anak mencapai usia tertentu.

Aspek kognitif diperlukan untuk memahami nilai-nilai dan norma-norma. Aspek emosi diperlukan untuk kepekaan lingkungan sekitar yang memungkinkan seseorang mampu berempati dan bertenggang rasa. Menurut Dewey dalam Sjarkawi (2006: 38) mengatakan "Ciri utama pendidikan moral adalah pendidikannya menggunakan perkembangan kognitif, disebut perkembangan kognitif karena menghargai pendidikan moral sebagai pendidikan intelektual yang mengusahakan timbulnya berpikir aktif dalam menghargai isu-isu moral dan menetapkan suatu keputusan moral.

Nilai moral seorang anak ditentukan oleh nilai perilaku baik atau buruk. Terbentuknya perilaku moral yang baik pada seseorang diperoleh melalui proses yang cukup panjang. Pembentukan perilaku moral tersebut secara sengaja harus dikenalkan dan ditanamkan sejak usia dini. Hermansyah (2000: 27) memaparkan bahwa upaya penanaman sikap atau perilaku moral kepada anak TK dapat dilakukan melalui (1) kegiatan rutin; (2) kegiatan spontan; (3) kegiatan dengan teladan; dan (4) kegiatan yang direncanakan.

Dari uraian di atas dapat disimpulkan pendidikan moral bertujuan membina terbentuknya perilaku moral yang baik bagi setiap orang. Hal ini mengartikan bahwa pendidikan moral bukan sekedar memahami tentang aturan benar atau salah, mengetahui ketentuan baik atau buruk, tetapi harus benar-benar meningkatkan perilaku moral seseorang. Berhasil tidaknya proses pembentukan perilaku moral pada seseorang, salah satu faktor yang sangat menentukan yaitu tergantung kepada efektif tidaknya upaya penanaman nilai moral kepada orang tersebut ketika masa kanak-kanak. Di sinilah letak pentingnya penanaman nilai moral kepada anak.

\section{Perilaku Moral}

Menurut Hurlock (1978 : 74), perilaku moral berarti perilaku yang sesuai dengan kode moral kelompok sosial. Hermansyah (2000 : 10) mengatakan bahwa perilaku moral adalah sikap dan perilaku seseorang yang mengikuti aturan nilai-nilai dan norma yang terdapat dilingkungannya.

Dari pendapat para ahli di atas dapat disimpulkan perilaku yang dapat disebut moralitas yang sesungguhnya tidak saja sesuai dengan standar sosial, melainkan juga dilaksanakan secara sukarela. la muncul bersamaan dengan peralihan kekuasaan eksternal ke internal dan terdiri atas tingkah laku yang diatur dari dalam, yang disertai perasaan tanggung jawab pribadi untuk tindakan masing-masing.

Pembiasaan perilaku merupakan aspek pengembangan yang utama yang harus dikembangkan pada anak usia dini. Perkembangan moral yang optimal pada anak usia dini yang tercantum dalam kurikulum KBK 2004 dengan indikatornya antara lain (1) anak mau memohon dan memberi maaf; (2) anak selalu berterima kasih jika memperoleh sesuatu; (3) anak senang menolong; serta (4) anak mau mengajak teman bermain dan belajar

Dari indikator di atas dapat dilihat bahwa penanaman moral sejak usia dini sangatlah penting. Anak akan belajar untuk melakukan kebaikan jika diarahkan melalui cerita - cerita yang berisikan nasihat atau berkomunikasi langsung.

Piaget dalam Hermansyah (2000: 19) dikenal sebagai penemu teori perkembangan kognitif, fokus perhatian Piaget adalah kaitan antara perkembangan moral yang terjadi pada seseorang dengan perkembangan kognitif orang tersebut. Teori tersebut terdiri dari tiga tahap yakni (1) tahap formal operasional; berpikir tentang berbagai hal atau isu yang bersifat abstrak seperti kejujuran, moralitas, kebebasan dan lain-lain. (2) tahap realisme moral; kepatuhan pada peraturan tanpa memahami alasan mengapa harus patuh, kepatuhan pada aturan semata-mata untuk menghindari hukuman yang akan diperoleh dari orang 
tua sebagai akibat dari perilaku yang salah. (3) Tahap moral-relativisme; anak mulai memandang aturan sebagai suatu kesepakatan sosial, dengan demikian dapat diubah tergantung dari alasan yang diberikan, anak menilai alasan benar atau salah atas dasar tujuan atau alasan dilakukannya perilaku tersebut.

Dari pendapat para ahli diatas dapat di simpulkan bahwa ada kaitan antara perkembangan moral yang terjadi pada seseorang dengan perkembangan kognitif orang tersebut. Untuk itu kita perlu menanamkan sikap perilaku baik tersebut sejak usia dini.

\section{Peranan Orang Tua dan Guru Dalam Meningkatkan} Perkembangan Moral

Menurut Santrock (2007: 117) menyimpulkan bahwa anak melewati 2 tahap yang berbeda dalam cara mereka berpikir secara moralitas yaitu:

1. Dari usia 4 sampai 7 tahun anak menunjukkan moralitas heteronom, tahap ini merupakan tahap pertama dimana anak berpikir bahwa keadilan dan peraturan adalah properti dunia yang tidak bisa diubah dan dikontrol oleh orang.

2. Dari usia 7 sampai 10 tahun anak berada dalam transisi menunjukan bagian dari ciri-ciri dari tahap pertama, perkembangan moral dan sebagian ciri tahap kedua moralitas otonom.

Kohlberg dalam Santrock (2007: 122) mengatakan "interaksi dengan teman sebaya adalah bagian penting dalam stimulasi yang menantang anak untuk merubah penalaran moral mereka". Proses memberi dan menerima diantara teman sebaya memberikan kesempatan pada anak untuk mengambil perspektif orang lain dan menghasilkan peraturan secara demokratis hubungan dengan teman sebaya memberikan kesempatan pada anak untuk memajukan penanaman moral anak.

Thomson dalam Santrock (2007: 133) mengatakan "hubungan orang tua dan anak memperkenalkan anak kepada kewajiban mutual dan hubungan interpersonal yang erat”. Kewajiban orang tua adalah terlibat dalam pengasuhan yang positif dan memandu anak menjadi manusia yang kompeten. Kewajiban anak merespon dengan sesuai terhadap inisiatif dari orang tua. Sikap yang harus dimilki oleh orang tua dan guru dalam penerapan moral anak menurut Santrock (2002: 134) adalah sebagai berikut:

1. Hangat dan mendukung, ketimbang menghukum.

2. Menggunakan disiplin induktif.

3. Memberikan kesempatan bagi anak dalam mempelajari dan memahami perasan orang lain.

4. Melibatkan anak dalam pengambilan keputusan keluarga dan proses pemikiran mengenai keputusan moral.
5. Menjadi model terhadap penalaran dan perilaku moral, dan menyediakan kesempatan bagi anak untuk juga melakukan hal tersebut.

6. Menyediakan informasi mengenai prilaku apa yang diharapkan dan mengapa.

7. Membangun moralitas internal dan eksternal.

Menurut Ellis dalam Musfiroh (2005: 79) menyatakan "bahwa perkembangan moral membutuhkan akal budi dan pendekatan analistis untuk menggali kepercayaan terhadap nilai-nilai dan kaidah". Kaidah perkembangan moral dapat distimulasi dengan berbagai metode, teknik dan materi, diantaranya dengan memberikan gambaran bagaimana berprilaku moral diterima dan didukung.

Dari penjelasan di atas dapat disimpulkan bahwa anak usia dini berada pada tahap pertama yaitu moralitas yang heteronom. Mereka menilai kebenaran atau kebaikan perilaku berdasarkan konsekuensinya bukan niat dari perilakunya. Pengaruh lingkungan dan keluarga adalah hal yang penting dalam pembentukan moral anak. Dalam hal ini peranan orang tua dan guru adalah merespon dan mengarahkan setiap prilaku ke arah yang baik dan memberi penjelasan dari setiap perilaku anak tersebut.

\section{Mendongeng}

Dongeng merupakan salah satu bentuk cerita rakyat. Menurut Abrams dalam Musfiroh (2005: 86) mengatakan "cerita rakyat meliputi mite, legenda dan dongeng". Ditambah lagi menurut Danandjaja dalam Agus D.S (2008: 11) dongeng termasuk ke dalam cerita rakyat lisan, lebih tepat lagi menurut dongeng adalah cerita khayali yang dianggap tidak benar-benar terjadi baik oleh penutur maupun oleh pendengarnya. Dongeng diceritakan terutama untuk hiburan walaupun banyak juga yang melukiskan kebenaran atau bahkan moral.

Dongeng merupakan cerita khayali yang dapat dijadikan sumber cerita untuk anak usia dini, terutama dongeng tentang binatang atau fabel dan cerita rakyat. Cukup banyak dongeng tentang binatang dan cerita rakyat yang dapat diceritakan kepada anak didik ditingkat TK, yang berisi kebenaran, ajaran moral, bahkan sindiran.

Agus D.S (2008: 14) yang disebut dengan mendongeng adalah kegiatan bercerita atau menuturkan cerita secara lisan. Masyarakat Indonesia sudah mengenal dongeng sejak zaman dahulu. Mereka mendongeng sambil bersifat religi. Kegiatan mendongeng kemudian diambil alih oleh orang tua, pengasuh, kakek dan nenek. Dongeng berkembang terus baik bentuk maupun ciri-cirinya. Mendongeng harus dilakukan dengan cara-cara yang benar seperti orang tua yang 
sedang memberi nasehat kepada anak yaitu dengan cara lemah lembut dan kasih sayang .

Dari penjelasan di atas dapat disimpulkan mendongeng bukanlah cara yang baru dalam memberikan pengajaran dan nasehat kepada anak. Cara mendongeng yang menyenangkan dan disukai oleh anak akan membantu orang tua dan pendidik dalam menanamkan sikap moral yang baik. Untuk itu para pendongeng harus memberikan cerita-cerita yang mendidik kepada anak.

Perkembangan moral anak sangat ditentukan pada saat usia dini, anak masih belajar untuk mengenal peristiwa-peristiwa yang mereka temui dan mulai belajar dari peristiwa tersebut. Untuk itu diperlukan kiat-kiat khusus bagaimana anak bisa belajar dengan baik dan mengambil nilai positif dari setiap peristiwa itu.

Menurut Nur'aini (2007: 9) dengan mendongeng kita bisa mengajari anak nilai-nilai kehidupan dan nilai keilahiyahan (ketuhanan) dengan cara yang menyenangkan. Dongeng memberikan bekal di dalam kehidupan mereka. Di dalam Al-Qur'an juga banyak ayat tentang kisah yang menceritakan kejadian masa lalu ataupun kisah para Rasul yang Allah berikan sebagai pelajaran bagi seluruh manusia.

Menurut farida Nur'ani (2007: 10-110) mengatakan ada beberapa manfaat mendongeng; (1) Mendongeng menjadi hubungan anak dan ibu semakin dekat; (2) Mendongeng sebagai sarana yang efektif dalam memberikan nilai-nilai kepada anak tanpa mereka merasa dinasehati secara langsung; (3) Kegiatan mendongeng mencerdaskan anak baik secara $E Q$ (Emotional Quotien) atau SQ (Spritual Quotien).

Agus D.S (2008: 83-87) yang merupakan seorang story teller atau pendongeng yang berbakat mengatakan manfaat mendongeng adalah (1) Mendongeng dapat menumbuhkan sifat empati anak; (2) Menambah kepercayaan diri anak; (3) Menanamkan kejujuran; (4) Dapat mengontrol keegoan anak; (4) Membersihkan akhlak.

Manfaat mendongeng ditambahkan lagi oleh Hollowel dalam Agus D.S (2007: 91) melalui bukunya yang berjudul "A book for children Literature" yang mengatakan bahwa ada 6 segi positif dari sebuah mendongeng: (1) Dongeng dapat mengembangkan imajinasi dan memberikan pengalaman emosional yang mendalam; (2) Memuaskan kebutuhan ekspresi anak; (3) Menanamkan pendidikan moral tanpa harus menggurui; (4) Menumbuhkan rasa humor yang sehat; (5) Mempersiapkan apresepsi sastra; (6) Memperluas cakrawala khayalan anak.

Selain itu cerita atau dongeng yang disampaikan memberikan pesan moral dan ajaran-ajaran budi perkerti bagi pendengarnya. Anak yang mendengarkan secara tidak sadar akan mengungkapkan imajinasi dan pikiran dengan bermain dan bergembira. Dongeng juga dapat memberikan dampak positif yang nyata terhadap kemampuan emosi anak sehingga akan terbentuk sikap kreatif, ramah, mudah bergaul dan terbangun empati lingkungan dan orang lain yang ada disekitarnya.

Dari penjelasan di atas dapat disimpulkan begitu banyak manfaat mendongeng bagi anak. Beberapa manfaat mendongeng di antaranya lebih banyak mengarah kepada moral anak.

\section{Kegiatan Mendongeng di Taman Kanak-kanak}

Mendongeng tidak hanya dilakukan oleh orang tua dalam menidurkan anaknya atau mengisi waktu senggang saja, tetapi mendongeng dapat dilakukan di sekolah bahkan dimana saja karena mendongeng tidak terikat akan tempat dan waktu dan juga tidak terikat siapa yang harus mendongeng. Sekarang, kegiatan bercerita atau menuturkan cerita secara lisan yang biasanya dilakukan oleh orang tua kepada anaknya lebih sering dilakukan di sekolah.

Pemahaman anak terhadap cerita tergantung pada proses menyimak. Menurut Aziz dan Majid (2003: 48) mengatakan "menyimak adalah usaha seorang anak dalam mengetahui cerita-cerita yang disampaikan padanya dan memahaminya serta menghayatinya ketika cerita itu berlangsung". Anak dalam umur yang masih dini tentulah tidak mampu mencurahkan perhatiannya terus menerus dan duduk dalam waktu yang lama dengan satu pola saja. Oleh karena itu guru harus memperhatikan bagaimana anak dapat menyimak cerita itu dengan baik seperti berikut: (a) bahwa perhatian murid ketika cerita berlangsung biasa bersifat paksaan. Hal ini tergantung bagaimana guru menarik perhatian mereka. (b) Sulit bagi murid selama cerita berlangsung untuk selalu berada pada posisi duduk. Oleh karena itu hendaknya seorang guru mengubah posisi duduk mereka disela-sela bercerita. (c) Seorang guru tidak boleh memenggal kesinambungan cerita, misalnya memerintahkan seorang murid agar mematuhi perintahnya, diam, atau tidak boleh bermain. (d) Ketika menyimak para murid akan berkhayal seakanakan mereka adalah tokoh dalam cerita. (e) Para murid ketika menyimak cerita bersama guru, diupayakan agar bisa merasakan dengan perasaan mereka akan berbagai kondisi seperti sedih, senang dan marah. (f) Anak-anak setelah mendengarkan cerita anak bisa saja mengungkapkan seluruh isi cerita atau sebagian. Misalnya dengan menjawab pertanyaan atau bercerita menurut bahasa sederhana.

Menurut Agus D.S (2009: 34) dongeng diyakini 
dapat mengembangkan kemampuan berimajinasi. Selain itu, dongeng juga sangat efektif untuk memotivasi daya kreasi anak. Karena itu anak lebih cepat menangkap pelajaran lewat dongeng, jadi tidak ada salahnya apabila para guru menyampaikan materi di sekolah dengan diselingi mendongeng. Cara ini tentu akan lebih menarik bagi anak:

a. Untuk lebih menarik perhatian anak, guru bisa menggunakan media seperti buku cerita, boneka, gambar berdasarkan pada cerita yang akan disampaikan.

b. Dalam kegiatan mendongeng ini guru bisa mengunakan metode bercerita, tanya jawab dan praktik langsung yang berguna dalam meningkatkan keaktifan dan kreativitas siswa dalam mendengarkan cerita.

Saat mendongeng di sekolah guru juga bisa mengajak si anak untuk turut berpartisipasi dan menumbuhkan rasa kebersamaan yang akrab. Saat guru sedang bercerita, guru bisa melibatkan anak untuk bersama-sama mengikuti gerak gerik guru sehingga anak tidak bosan dalam mendengarkan dongeng.

Mendongeng merupakan suatu penyegaran bagi anak selama melakukan aktivitas atau kegiatan di sekolah. Cerita-cerita yang disampaikan kepada mereka hendak sesuai dengan usia dan perkembangan anak. Anak dapat merasakan pengalaman emosional secara langsung juga kebersamaan dan persahabatan.

Dari penjelasan di atas dapat disimpulkan proses menyimak adalah hal penting bagi anak dalam memahami cerita dibutuhkan cara agar anak dapat menyimak cerita dengan baik. Hal tersebut juga didukung oleh media dan metode yang digunakan guru sehingga menarik minat anak dalam menyimak cerita.

Menurut Kusumo (2006: 16) mengatakan ada beberapa cara mendongeng yang perlu diketahui oleh guru dan orang tua, yaitu (1) mendongeng tanpa alat peraga seperti yang dilakukan nenek atau ibu sambil membelai kepala anaknya; dan (2) mendongeng dengan alat peraga. Pendongeng bisa mendongeng dengan cara membaca buku cerita bergambar, memainkan boneka atau dibantu dengan gambar.

Dalam menyampaikan sebuah cerita usahakan menggunakan bahasa yang mudah dipahami oleh anak-anak. Sampaikanlah cerita dengan yang menarik agar anak jadi tertarik dan betah mendengarkan cerita yang disampaikan.

Setelah kita dapat memilih cerita dan membuat yang tepat untuk anak usia dini, kita pun membutuhkan teknik untuk menjadikan cerita itu lebih hidup, menyenangkan dan disukai oleh anak. Dalam hal ini dibutuhkan kiat-kiat khusus.

Menurut Agus D.S (2006: 110) mengemukakan ada beberapa teknik yang harus dikuasai oleh pendongeng yaitu:

1. Pastikan kondisi fisik dalam keadaan baik.

2. Berusahalah untuk memfokuskan perhatian saat bercerita.

3. Hayatilah sungguh-sungguh cerita yang akan anda bawakan.

4. Buatlah singkatan cerita di sepotong kertas atau membuat semacam kartu cerita.

5. Bila anda mampu cobalah berpuisi, menyanyikan atau memainkan alat musik sebagai pelengkap dongeng.

6. Agar dongeng menjadi lebih menarik, cobalah memilih adegan menarik untuk dramatisasikan berulang-ulang.

7. Atur dan perbaikan artikulasi dalam pengucapan kata-kata agar terdengar jelas.

8. Ajukan pertanyaan kepada anak-anak dengan tibatiba sambil menyentuh dan mengusap mereka.

9. Gunakan intonasi yang tepat seperti lembut, keras, pelan, berteriak atau menirukan suara binatang dari setiap tokoh cerita.

10. Buat kesimplan pada akhir cerita sehingga anak lebih bisa memahami isi dan cerita tersebut.

Dari penjelasan di atas kita dapat mengetahui bahwa cara atau teknik mendongeng itu sangat mudah untuk kita pelajari. Bagi guru, mereka bisa melakukan di sekolah dan bagi orang tua, mereka bisa melakukan di rumah sebagai salah satu bentuk hubungan erat antara orang tua dan anak.

Begitu pentingnya mendongeng dan begitu banyak manfaatnya bagi anak usia dini, hendaknya guru taman kanak-kanak dapat menerapkan mendongeng ini sabagai salah satu bentuk strategi pembelajaran dalam pembentukan moral anak sehingga akan melahirkan anak-anak bangsa yang berkepribadian yang baik dan berbudi pekerti luhur.

Perkembangan moral merupakan suatu proses perubahan sikap perilaku dalam mengenal dan memahami setiap perbuatan mengenai benar atau salah, baik atau buruk dalam kehidupan suatu anggota budaya masyarakat. Perkembangan moral dapat kita bentuk sejak usia dini dengan memberikan berbagai pengarahan, bimbingan dan nasehat dalam mengajarkan sikap perilaku yang baik dan berguna bagi kehidupan. Hal ini dapat dilakukan dengan kegiatan bercerita salah satunya mendongeng. Mendongeng merupakan kegiatan bercerita yang menyenangkan bagi anak usia dini.

Suminto (2008: 4) mengatakan dongeng 
sebagai salah satu sarana untuk mendidik anak, dongeng menjadi pesantren alternatif yang mengenalkan mereka kepada berbagai nilai luhur. Pernyataan ini juga diperkuat lagi oleh Agus D.S (2009: 34) yang mengatakan dongeng merupakan sarana pembelajaran nilai-nilai moral bagi anak. Saat mendongeng di sekolah kita bisa memilih tema tentang kebaikan yang sering dialami dalam kehidupan sehari-hari.

Musfiroh (2005: 95) mengatakan cerita atau dongeng memiliki keuntungan psikologis yang tidak diperoleh jika anak menyaksikan cerita yang sama melalui media audio visual. Banyak VCD cerita rakyat memang membuat anak-anak memperoleh informasi mengenai cerita, tetapi mereka tidak mempunyai kedekatan dan kebersamaan dengan si pencerita. Efek psikologis inilah yang menjadi landasan bagi guru untuk menyemaikan nilai-nilai moral, etika, dan pekerti. Penyemaian ini membantu anak belajar mengidentifikasi permasalahan , termasuk juga belajar mengidentifikasi masalah dan menilai diri sendiri.

Anak yang terbiasa memperoleh kebahagian melalui berbagai kegiatan, termasuk saat-saat menyimak dongeng, akan tumbuh menjadi pribadi hangat, kompromis dan memiliki kecerdasan interpesonal yang tinggi daripada anak-anak yang tidak memperoleh kesempatan itu. Guru dan orang tua yang berperan sebagai tukang cerita memliki sentral sebagai tempat bertanya dan berbagi. Hubungan psikologis ini membuka peluang bagi orang tua dan guru untuk mentransmisikan ajaran moral pada anak.

Dari penjelasan di atas dapat disimpulkan bahwa penanaman moral yang baik sejak usia dini sangatlah penting dalam membentuk sikap prilaku anak.

\section{Kerangka Konseptual}

Kegiatan mendongeng merupakan suatu kegiatan yang menyenangkan dalam membarikan penanaman moral kepada anak. Buku cerita dongeng yang mendidik dan berisi pesan moral tentu akan memberikan pengajaran tentang bersikap prilaku kepada anak. Guru dapat memilih cerita dongeng yang berguna bagi kehidupan anak seperti mendongeng agar saling menyayangi teman, senang menolong, mau memohon dan memberi maaf serta selalu mengucapkan terima kasih jika memperoleh sesuatu. Cara dan teknik mendongeng yang menyenangkan tentu akan membantu anak dalam memahami isi cerita, membedakan perbuatan baik dan buruk dalam setiap peristiwa dan mengetahui akibat dari setiap perbuatan yang kita lakukan serta dapat melatih sikap perilaku yang baik pada diri anak sehingga perkembangan moral anak meningkat. Melalui kegiatan mendongeng yang menyenangkan pada anak usia dini akan dapat meningkatkan pengembangan moral anak kearah yang lebih baik. Hal ini dapat dilihat pada gambar 1.

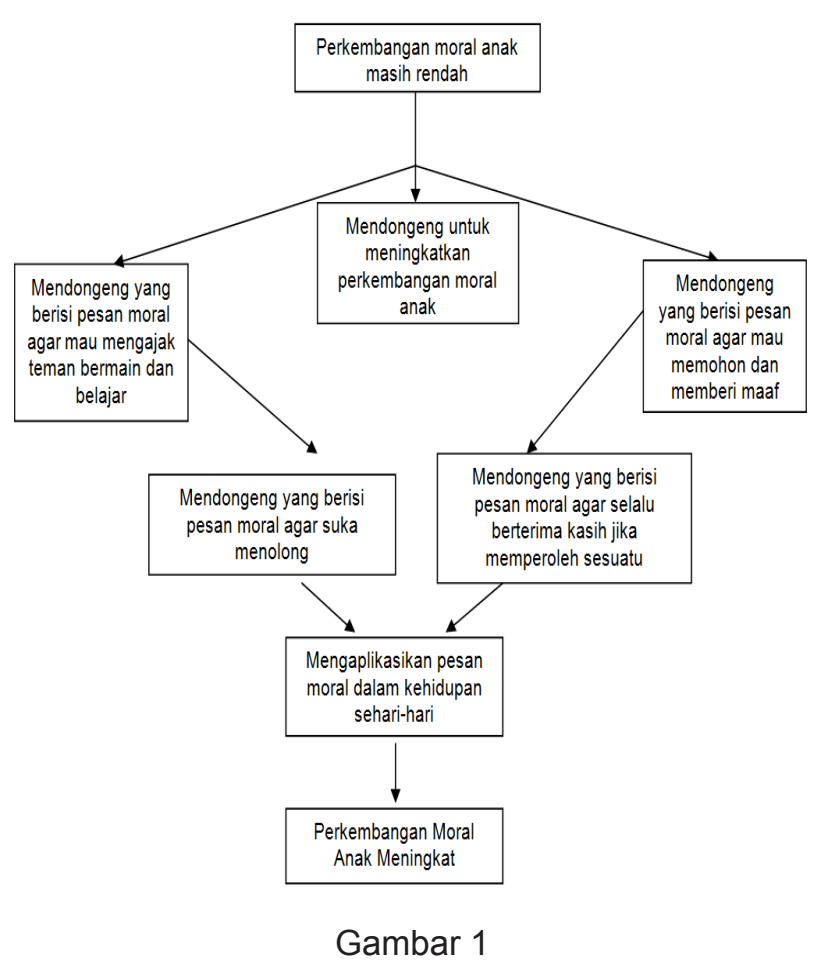

Pengembangan Anak Melalui Kegiatan Mendongeng

\section{METODOLOGI PENELITIAN}

Jenis penelitian ini adalah penelitian tindakan kelas (classroom action research). Darmansyah (2009: 9) mengatakan PTK merupakan penelitian tindakan kelas yang berupaya untuk meningkatkan kualitas pembelajaran. Penelitian kelas ini dilakukan agar meningkatkan kinerja guru sehingga menjadi profesional dan refleksi diri sehingga hasil belajar siswa menjadi lebih baik.

Penelitian tindakan kelas ini dilakukan di TK Dharmawanita UNP Padang. Subjek penelitian ini adalah kelompok B1 di TK Dharmawanita UNP
Padang dengan jumlah peserta didik sebanyak 17 orang yang terdiri dari 10 anak laki-laki dan 7 orang anak perempuan.

Pelaksanaan penelitian ini memakan waktu lebih kurang 2 bulan, yaitu dari bulan September 2011 hingga Oktober 2011. Penelitian ini terdiri dari 2 siklus yang mana masing-masing siklus terdiri dari 2 kali pertemuan yang dimulai dari kegiatan awal (30 menit), kegiatan inti (60 menit) dan kegiatan penutup (30 menit).

Objek penelitian adalah kegiatan mendongeng 
dalam meningkatkan perkembangan moral anak di TK Dharmawanita UNP Padang di kelas B1 yang meliputi kegiatan guru dan anak didik serta hasil belajar selama proses belajar mengajar berlangsung.

Prosedur dalam penelitian ini terdiri dari beberapa komponen. Menurut Suharsimi (2006: 16) komponen tersebut terdiri atas perencanaan (plan), pelaksanaan (action), pengamatan (observasi), dan perenungan. Penelitian yang dilakukan ini terdiri dari 2 siklus. Masing-masing siklus terdiri dari 2 kali pertemuan. Jika masalah pada siklus I belum terpecahkan, maka dapat dilanjutkan ke siklus II yang didasarkan pada hasil siklus sebelumnya.

\section{Kondisi awal}

Sebelum melakukan tindakan terlebih dahulu peneliti mengetahui kondisi awal yaitu masih rendahnya perkembangan moral anak di TK Dharmawanita UNP Padang pada kelompok B1. Setelah mengetahui permasalahan dan hasil pengamatan dianalisis maka peneliti melakukan tindakan yang dimulai dari siklus I yang terdiri dari 2 kali pertemuan.

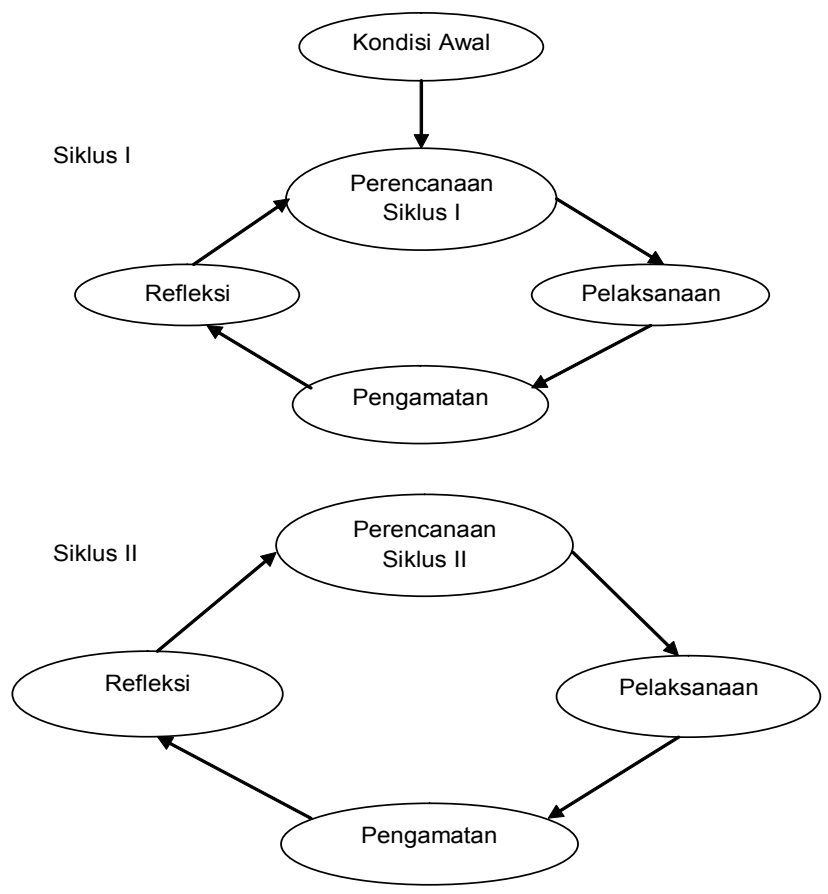

Gambar 2 Prosedur Tindakan Kelas

Siklus I

Kegiatan Tindakan

A. Perencanaan

Perencanaan yang akan dilakukan dalam penelitian ini adalah membuat rencana pembelajaran berupa satuan kegiatan mingguan dan satuan kegiatan harian yang berisikan tentang kegiatan mendongeng.

\section{B. Pelaksanaan}

1. Pertemuan I

Pelaksanan terdiri dari tiga tahap: a. Kegiatan awal; (1) setelah anak masuk ke dalam kelas dan duduk seperti lingkaran dan memberi salam kepada ibu guru. (2) Guru memulai kegiatan dengan bernyanyi dan melanjutkan dengan berdo'a. (3) Guru bercerita tentang tema hari ini bersama anak.

b. Kegiatan inti; (1) guru mendongengkan cerita kepada anak. (2) Setelah selesai bercerita guru mengadakan tanya jawab bersama anak tentang cerita yang telah disampaikan. (3) Anak mengulang cerita dongeng menurut bahasa anak sendiri. (4) Anak mengambil pesan moral dari cerita dongeng tersebut.

b. Kegiatan penutup; (1) guru melakukan evaluasi kegiatan bersama anak. (2) Guru dan anak berdo'a dan bernyanyi bersama

2. Pertemuan II

a. Kegiatan awal; (1) guru dan anak mengucapkan salam dan berdo'a bersama. (2) Guru mengambil absen dan menanyakan kabar anak hari ini. (3) Guru bercerita tentang tema hari ini bersama anak

b. Kegiatan inti; (1) guru mendongengkan cerita kepada anak. (2) Setelah selesai bercerita, guru mengadakan tanya jawab bersama tentang cerita yang telah disampaikan. (3) Anak mengulang cerita dengan bahasa mereka sendiri. (4) Anak mengambil pesan moral dari cerita tersebut.

c. Kegiatan Penutup; (1) guru melakukan evaluasi kegiatan bersama anak. (2) Guru dan anak berdo'a dan bernyanyi bersama.

3. Pengamatan

Hal ini dapat dilakukan dengan kegiatan mengenali, memperhatikan, mencatat, dan juga mendokumentasikan perubahan-perubahan sikap perilaku anak ke arah yang lebih baik. Observasi ini dilakukan untuk mengumpulkan data selama penelitian.

4. Perenungan atau Refleksi

Merumuskan tindakan yang perlu dilakukan selanjutnya dan menjelaskan bagaimana melakukannya. Perenungan dilakukan setelah kegiatan selesai dan mengetahui hasil yang telah dicapai, apakah perlu tindak lanjut pada penelitian berikutnya.

Sumber data dari penelitian ini adalah data yang didapat dari hasil pengamatan tentang kegiatan anak selama kegiatan mendongeng dilakukan dan proses perubahan sikap perilaku anak selama proses belajar mengajar, hasil wawancara, dokumentasi, dan catatan lapangan

\section{Alat dan Teknik Pengumpulan Data}

Alat yang digunakan untuk mengukur aktivitas anak dalam kegiatan pembelajaran menurut Arikunto 
(2006: 24) adalah format observasi untuk anak digunakan dalam mencatat kegiatan pembelajaran yang dilakukan guru dan anak. Selain itu, format wawancara dilakukan untuk tanggapan keaktifan siswa terhadap kegiatan setelah kegiatan pembelajaran berlangsung. Sehingga penulis menggunakan kamera sebagai alat dokumentasi dan field note yang digunakan sebagai catatan hasil pengamatan setiap kali pertemuan.

Pengumpulan data dilakukan dengan pengamatan tentang kegiatan anak selama proses belajar mengajar berlangsung. Di samping itu, wawancara juga dilakukan kepada anak tentang cerita dongeng yang telah diceritakan oleh anak dengan format seperti tabel 1.

Tabel 1. Format Wawancara

\begin{tabular}{|c|l|c|c|}
\hline No & \multicolumn{1}{|c|}{ Pertanyaan } & Jawaban & Alasan \\
\hline 1. & $\begin{array}{l}\text { Bagaimana perasaan } \\
\text { anak ibu ketika men- } \\
\text { dengar cerita dongeng } \\
\text { ibu tadi? }\end{array}$ & - & - \\
\hline 2. & $\begin{array}{l}\text { Apa judul cerita yang } \\
\text { anak ibu suka? }\end{array}$ & - & - \\
\hline 3. & $\begin{array}{l}\text { Siapakah tokoh dalam } \\
\text { cerita dongeng tadi yang } \\
\text { anak ibu suka? }\end{array}$ & - & - \\
\hline 4. & $\begin{array}{l}\text { Apakah anak ibu mau } \\
\text { meniru perilaku baik } \\
\text { dalam cerita dongeng } \\
\text { ibu? }\end{array}$ & - & - \\
\hline
\end{tabular}

Tidak hanya pengamatan dan wawancara yang perlu dilakukan, tetapi mendokumentasikan dengan memotret kegiatan anak dalam mendengarkan cerita dan perubahan terhadap setiap sikap perilaku anak juga dilakukan selama proses belajar mengajar berlangsung. Catatan di lapangan perlu adanya yang bertujuan agar mengetahui perubahan sikap perilaku anak yang dimulai dari kegiatan awal, kegiatan inti, dan kegiatan penutup. Berikut adalah contoh catatan di lapangan pada tabel 2 .

Tabel 2. Catatan Lapangan Guru

\begin{tabular}{|c|c|}
\hline Pertemuan 1 & $\begin{array}{c}\text { Catatan Proses } \\
\text { Pembelajaran }\end{array}$ \\
\hline $\begin{array}{c}1 \\
\text { Aktivitas Sebelum Mengajar } \\
\text { (Pre-teaching Activities) }\end{array}$ & \\
\hline $\begin{array}{c}2 \\
\text { Aktivitas Sedang Mengajar } \\
\text { (Whilst-teaching Activities) }\end{array}$ & \\
\hline $\begin{array}{c}3 \\
\text { Aktivitas Penutup } \\
\text { (Post-teaching Activities) }\end{array}$ & \\
\hline
\end{tabular}

\begin{tabular}{|c|c|}
\hline Pertemuan 2 & $\begin{array}{c}\text { Catatan Proses } \\
\text { Pembelajaran }\end{array}$ \\
\hline $\begin{array}{c}1 \\
\text { Aktivitas Sebelum Mengajar } \\
\text { (Pre-teaching Activities) }\end{array}$ & \\
\hline $\begin{array}{c}2 \\
\text { Aktivitas Sedang Mengajar } \\
\text { (Whilst-teaching Activities) }\end{array}$ & \\
\hline $\begin{array}{c}3 \\
\text { Aktivitas Penutup } \\
\text { (Post-teaching Activities) }\end{array}$ & \\
\hline
\end{tabular}

\section{Analisis data}

Gay dan Air Asia (2000: 240) mengatakan dalam mengelola data ada empat tahap yang harus dilakukan yang meliputi membaca data, mendeskripsikan data, mengelompokkan data, dan menginterpretasikannya berdasarkan alat yang digunakan dalam pengumpulan data.

Menurut Hariyadi (2009: 24) data yang diperoleh selama penelitian berlangsung dianalis dengan teknik persentase. Data yang dianalisis dengan menggunakan rumus untuk mengukur peningkatan kreativitas anak sebagai berikut.

$$
P=F / N \times 100 \%
$$

Keterangan:

$\mathrm{P}=$ angka prestasi

$\mathrm{F}=$ frekuensi aktivitas siswa

$\mathrm{N}=$ jumlah anak dalam satu kelas

Keberhasilan pembelajaran dikatakan meningkat jika persentase hasil dari pengamatan perkembangan sikap perilaku anak meningkat dari hasil pengamatan sebelumnya.

Selain dari analisis secara kuantitatif, peneliti perlu melakukan analisis secara kualitatif berupa narasi yang dikriteriakan oleh Arikunto (2006: 241) dilambangkan dengan Sangat Tinggi (ST), Tinggi (T), dan Rendah (R). Hal ini mengenai peningkatan moral anak.

\section{1. $81 \%$ - $100 \%$ Sangat Tinggi}

- Memahami nasehat cerita dan dapat menerapkan dalam kehidupan

2. $61 \%-80 \%$ Tinggi

- Memahami nasehat cerita dan masih membutuhkan arahan

\section{3. $21 \%-59 \%$ Rendah}

- Tidak dapat memahami nasehat cerita dan tidak bisa menerapkan

Data yang digunakan sebagai bahan untuk menentukan tindakan berikutnya. Keseluruhan data digunakan mengambil kesimpulan dari tindakan yang dilakukan dan pengaruhnya terhadap peningkatan 
mutu pembelajaran. Hasil analisis ini akan dimasukkan ke dalam laporan hasil penilaian.

Keberhasilan kegiatan mendongeng menurut Bentri ( 2005: 10) ditandai dengan beberapa hal, seperti (1) $75 \%$ anak dapat memahami isi cerita; dan (2) $75 \%$ kemampuan perkembangan moral anak meningkat.

\section{HASIL DAN PEMBAHASAN}

Setelah peneliti melakukan pengamatan di TK Dharmawanita UNP Padang ditemukan bahwa perkembangan moral anak masih sangat rendah, diantaranya masih banyak anak-anak yang belum memahami perbuatan baik atau buruk yang dilakukan. Deskripsi Awal

Pada saat peneliti mengamati kondisi awal anak hari Selasa tanggal 6 September 2011 tentang sikap perilaku anak tersebut, ternyata hal ini disebabkan karena masih banyak anak kurang memahami baik atau buruk dari perbuatan yang mereka lakukan. Hal ini dapat terlihat jelas pada tabel 3 .

Tabel 3.

Observasi Sikap Perilaku dalam Meningkatkan Perkembangan Moral Anak melalui Mendongeng Pada Kondisi Awal (Sebelum Tindakan)

\begin{tabular}{|c|c|c|c|c|c|c|c|}
\hline \multirow{3}{*}{ No. } & \multirow{3}{*}{ Aspek } & \multicolumn{6}{|c|}{ Nilai } \\
\hline & & \multicolumn{2}{|c|}{$\begin{array}{c}\text { Sangat } \\
\text { Tinggi } \\
\text { (ST) }\end{array}$} & \multicolumn{2}{|c|}{$\begin{array}{l}\text { Tinggi } \\
\text { (T) }\end{array}$} & \multicolumn{2}{|c|}{$\begin{array}{l}\text { Rendah } \\
\text { (R) }\end{array}$} \\
\hline & & $\begin{array}{l}\text { Jml } \\
\text { anak }\end{array}$ & $\%$ & \begin{tabular}{|l|} 
Jml \\
anak
\end{tabular} & $\%$ & $\begin{array}{c}\mathrm{Jml} \\
\text { anak }\end{array}$ & $\%$ \\
\hline 1 & $\begin{array}{l}\text { Anak dapat } \\
\text { mengajak teman } \\
\text { bermain dan } \\
\text { belajar }\end{array}$ & 2 & 11.76 & 4 & 23.52 & 11 & 64.47 \\
\hline 2 & $\begin{array}{l}\text { Anak senang } \\
\text { menolong }\end{array}$ & 3 & 17.64 & 4 & 23.52 & 10 & 58.82 \\
\hline 3 & $\begin{array}{l}\text { Saling memohon } \\
\text { dan memberi maaf }\end{array}$ & 2 & 11.76 & 3 & 17.64 & 12 & 70.58 \\
\hline 4 & $\begin{array}{l}\text { Anak selalu } \\
\text { berterima kasih } \\
\text { jika memperoleh } \\
\text { sesuatu }\end{array}$ & 2 & 11.76 & 2 & 11.76 & 13 & 76.47 \\
\hline Nilai & rata-rata & 2.25 & 13.23 & 3.25 & 19.11 & 11.5 & 67.58 \\
\hline
\end{tabular}

ST (Sangat Tinggi) : Anak dapat memahami nasehat cerita dan menerapkan nasehat dalam kehidupan.

T (Tinggi) : : Anak dapat memahami nasehat dalam cerita tetapi masih membutuhkan arahan

R (Rendah) : :Tidak dapat memahami nasehat cerita dan belum bisa menerapkan dalam kehidupan.
Dari tabel di atas tergambarlah perkembangan moral anak masih rendah pada kondisi awal. Hal ini dapat terlihat pada ke empat aspek di atas, anak dapat mengajak teman bermain dan belajar, anak senang menolong, anak mau memohon dan memberi maaf, serta anak selalu berterima kasih jika memperoleh sesuatu. Oleh karena itu, diperlukan penelitian untuk meningkatkan ke empat aspek tersebut. Sikap anak mendengarkan cerita untuk perkembangan moral juga sangat rendah, hal ini terlihat dari sikap anak yang masih kurang senang dan kurang bersemangat.

Tabel 4.

Sikap Anak Mendengarkan Cerita dalam Meningkatkan Perkembangan Moral Anak melalui Mendongeng Pada Kondisi awal (Sebelum Tindakan)

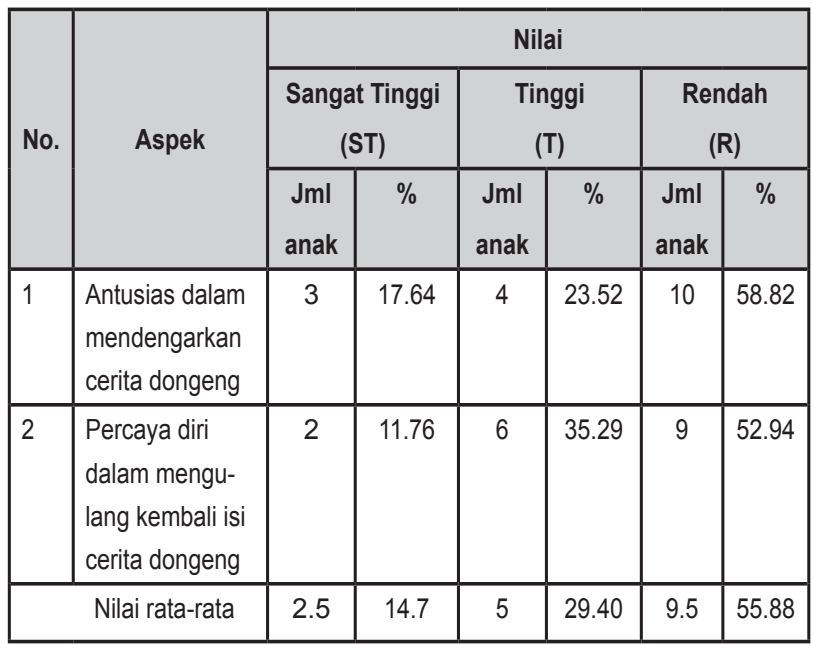

Dari uraian tabel di atas tergambarlah sikap anak dalam mendengarkan cerita untuk meningkatkan perkembangan moral anak yang masih rendah. Untuk itu peneliti perlu melaksanakan penelitian yang dimulai dari siklus I pertemuan I dan II.

Deskripsi hasil penelitian diuraikan dalam tahapan yang berupa siklus-siklus yang dilakukan pada kegiatan dalam siklus sebagai berikut.

\section{Deskripsi siklus I}

Siklus I pertemuan pertama dilakukan pada hari Jum'at tanggal 9 September 2011, selanjutnya pertemuan kedua hari Senin tanggal 12 September 2011. Secara keseluruhan tindakan pada siklus I dapat dilaksanakan sesuai dengan rancangan yang telah 
dibuat sebelumnya dengan langkah sebagai berikut: a. Perencanaan.

Penelitian melakukan analisis kurikulum untuk menentukan kompetensi dasar dan indikator. Guru melaksanakan proses pembelajaran untuk meningkatkan perkembangan moral anak sesuai dengan satuan kegiatan harian (SKH) yang telah direncanakan. Kompetensi dasar diambil dari pembentukan perilaku dan kemampuan berbahasa. Dari pembentukan perilaku kompetensi dasarnya adalah anak mau melakukan ibadah, terbiasa mengikuti aturan dan dapat hidup bersih dan mulai belajar membedakan benar dan salah dan terbiasa berperilaku terpuji. Hasil belajar dari kompetensi dasar ini adalah terbiasa berperilaku sopan santun dengan indikator selalu berterima kasih jika memperoleh sesuatu. Terbiasa menunjukan kepedulian dengan indikatornya adalah senang menolong, mau memohon dan memberi maaf serta mengajak teman bermain dan belajar.

Metode yang digunakan dalam kegiatan ini adalah bercerita, tanya jawab, dan praktik langsung serta mempersiapkan media-media pendukung seperti buku-buku cerita dongeng yang sesuai dengan perkembangan anak, boneka atau gambar.

b. Tindakan

Peneliti melaksanakan proses kegiatan mendongeng dengan menyiapkan media buku-buku cerita untuk anak usia dini dengan satuan kegiatan harian yang telah disusun, pertemuan pertama dilakukan pada hari Kamis tanggal 8 September 2011 dengan langkah-langkah sebagai berikut (1) peneliti menyiapkan buku cerita dongeng yang akan diceritakan kepada anak. (2) Pada pertemuan pertama ini peneliti menggunakan media bantu boneka tangan. Sebelum peneliti mendongeng, peneliti bertanya kepada anak tentang tentang nama-nama binatang buas. (3) Setelah anak terkondisikan dengan baik, peneliti mengeluarkan buku cerita yang berjudul "Sapi dan Singa yang saling menolong". (4) Setelah selesai peneliti menyuruh anak untuk mengulang cerita tersebut menurut bahasa anak sendiri dan untuk menilai sejauh mana anak memahami cerita yang telah dibacakan oleh pendongeng. (5) Pada kegiatan terakhir guru mengadakan tanya jawab bersama anak tentang cerita dongeng. (6) Peneliti dan anak dapat mengambil nasehat dari cerita tersebut yaitu kita harus berbuat baik kepada teman, agar kita mempunyai banyak teman dan janganlah kita menjadi orang yang angkuh serta sombong dengan kelebihan yang kita punyai tapi jadikanlah kelebihan itu untuk menolong orang lain. Perubahan sikap perilaku anak pada siklus I pertemuan pertama ini dapat peneliti amati dan peneliti uraikan pada catatan lapangan setelah siklus I selesai.

Pertemuan kedua dilakukan pada hari Selasa tanggal 12 September 2011 dengan proses kegiatan sebagai berikut: pada pertemuan kali ini guru mendongeng sebuah cerita yang berjudul "Bebek yang baik hati" dengan menggunakan alat bantu sebuah gambar yang melukiskan empat ekor bebek, 1 ekor induk dan 3 ekor anaknya. Dengan langkah kegiatan sebagai berikut: (1) Peneliti dan anak duduk di atas karpet. Guru dan anak telah bercerita tentang binatang yang suka berenang. (2) Peneliti telah mempersiapkan gambar yang akan digunakan dan juga telah menguasai alur cerita dongeng. (3) Peneliti memperlihatkan gambar bebek secara tiba-tiba kepada anak dan mulai mendongengkan cerita dengan memperkenalkan judul cerita kepada anak. (4) Setelah selesai bercerita peneliti menyuruh anak untuk mengulang cerita dengan bahasa mereka sendiri hal ini untuk menilai sejauh mana pemahaman anak tentang isi dongeng yang telah diceritakan. Peneliti lebih memberikan arahan kepada anak yang selama ini masih belum suka berterima kasih dan sombong. (5) Peneliti pun mangadakan tanya jawab bersama dengan anak tentang isi cerita. (6) Peneliti dan anak mengambil nasehat dan pesan dalam cerita yaitu jadilah anak yang baik, ramah dan selalu berterima kasih jika mendapat sesuatu dari orang lain, karena dengan sifat kita yang seperti itu maka kita akan disenangi oleh banyak orang dan orang akan senantiasa senang menolong kita karena kita anak yang baik.

Pada akhir siklus pertama ini dari hasil pengamatan peneliti maka peneliti dapat mengambil kesimpulan yaitu (1) proses belajar mengajar berlangsung sesuai rencana. (2) Anak sudah dapat mengenal, membedakan sifat baik dan buruk dan meniru sifat baik seperti: saling menyayangi teman, menjadi anak yang jujur, suka berterima kasih dan saling menolong. Anak juga dapat mengenal perbuatan buruk dan tidak mau menirunya seperti berbohong, jahat kepada teman, serta sombong.

\section{c. Pengamatan}

Berdasarkan kegiatan pembelajaran yang telah dilakukan, maka peneliti mendapatkan sebagai berikut, anak merasa tertarik dan berminat untuk mengikuti kegiatan mendongeng, anak dapat mengulang cerita dengan bahasa yang sederhana, anak sudah dapat membedakan perbuatan yang baik dan buruk dalam cerita, anak dapat menerapkan pesan dan nasehat cerita dalam kehidupan. Masih ada beberapa anak yang belum beminat mendengarkan cerita dongeng dan belum bisa menerapkan pesan dongeng dalam kehidupan. Perubahan sikap perilaku anak tersebut 
dapat dilihat pada tabel 5 catatan lapangan.

Tabel 5. Catatan Lapangan guru siklus I

\begin{tabular}{|c|c|}
\hline Pertemuan I & Catatan Perubahan Sikap Perilaku Anak \\
\hline $\begin{array}{c}1 \\
\text { Kegiatan Awal } \\
\text { (Pre-teaching } \\
\text { activities) }\end{array}$ & $\begin{array}{l}\text { Pada saat kegiatan awal peneliti mengamati } \\
\text { sikap anak yang masih belum tenang. Anak } \\
\text { masih suka mengganggu temannya yang } \\
\text { sedang ayik memperhatikan guru. Andi, } \\
\text { yuda, riko selalu berpindah-pindah tempat } \\
\text { duduk sehingga keadaan kelas sedikit ribut. }\end{array}$ \\
\hline $\begin{array}{c}2 \\
\text { Kegiatan Inti } \\
\text { (Whilst-teaching } \\
\text { activites) }\end{array}$ & $\begin{array}{l}\text { Guru mengajukan pertanyaan kepada anak, } \\
\text { siapa yang suka menolong, namun banyak } \\
\text { anak yang tidak mengacungkan tangannya. } \\
\text { Anak terpana ketika guru mengeluarkan } \\
\text { boneka tangan sapi dan singa dan mulai } \\
\text { mendongeng. Perhatian anak-anak mulai } \\
\text { tertarik pada cerita guru. Selesai cerita guru } \\
\text { pun memberikan nasehat kepada anak agar } \\
\text { kita saling menolong }\end{array}$ \\
\hline $\begin{array}{c}3 \\
\text { Kegiatan Penutup } \\
\text { (Post-teaching } \\
\text { activities) }\end{array}$ & $\begin{array}{l}\text { Peneliti memperhatikan ketika arya terjatuh } \\
\text { davin berlari dan menolongnya. Nisa, dewi } \\
\text { dan rahmi telah mau berbagi ayunan de- } \\
\text { ngan teman yang lain. Hal ini menunjukan } \\
\text { pesan dalam cerita mulai dipahami anak } \\
\text { dengan baik. }\end{array}$ \\
\hline Pertemuan II & Catatan Perubahan Sikap Perilaku Anak \\
\hline $\begin{array}{c}1 \\
\text { Kegiatan Awal } \\
\text { (Pre-teaching } \\
\text { activities) }\end{array}$ & $\begin{array}{l}\text { Anak sudah mulai tertarik dengan mendo- } \\
\text { ngeng, karena pada kesempatan kali ini } \\
\text { anak yang meminta untuk didongengkan. } \\
\text { Mereka sudah mulai tenang dalam men- } \\
\text { dengarkan cerita. Davin, arya yang selalu } \\
\text { bergelut pindah duduk ke depan untuk men- } \\
\text { dengarkan cerita dongeng hari ini. }\end{array}$ \\
\hline $\begin{array}{c}2 \\
\text { Kegiatan Inti } \\
\text { (Whilst-teaching } \\
\text { activites) }\end{array}$ & $\begin{array}{l}\text { Guru mendongeng dengan menggunakan } \\
\text { gambar. Anakpun berkata "gambarnya } \\
\text { bagus". Guru mulai mendongeng dan mem- } \\
\text { perhatikan sikap anak yang sudah mulai } \\
\text { tenang dalam mendengarkan cerita. Setelah } \\
\text { selesai bercerita, guru pun bertanya kepada } \\
\text { anak, "siapa yang mau meniru bebek yang } \\
\text { baik hati'? hampir semua anak menunjuk } \\
\text { tangannya ke atas. }\end{array}$ \\
\hline $\begin{array}{c}3 \\
\text { Kegiatan Penutup } \\
\text { (Post-teaching } \\
\text { activities) }\end{array}$ & $\begin{array}{l}\text { Peneliti memperhatikan anak sudah mulai } \\
\text { menyukai dongeng dan sudah mulai dapat } \\
\text { memahami pesan cerita dengan baik. } \\
\text { Karena sudah mulai nampak pada sikap } \\
\text { perilakunya anak sehari- hari di sekolah }\end{array}$ \\
\hline
\end{tabular}

Dari hasil catatan lapangan di atas terlihatlah perubahan terhadap sikap dan perilaku anak dalam proses pembelajaran. Anak yang masih belum memahami baik atau buruk dari perbuatan mereka, setelah guru mendongeng pada siklus I anak sudah dapat membedakan baik atau buruk dari perbuatannya serta sudah dapat menerapkan dalam kehidupan.

Setelah membuat catatan lapangan yang berkaitan dengan kegiatan awal, kegiatan inti, dan kegiatan akhir pada setiap pertemuan, maka peneliti melakukan tanya jawab kepada anak tentang kegiatan yang telah dilakukan. Berikut adalah hasil tanya jawab antara guru dan murid.

Tabel 6. Lembar Wawancara Anak Pada Siklus I (Setelah Tindakan) Pertemuan III

\begin{tabular}{|c|c|c|c|}
\hline No & Pertanyaan & Jawaban & Alasan \\
\hline \multirow[t]{2}{*}{1.} & $\begin{array}{l}\text { Bagaimana } \\
\text { perasaan anak- } \\
\text { anak ibu ke- } \\
\text { tika mendengar } \\
\text { cerita dongeng } \\
\text { ibuk tadi? }\end{array}$ & $\begin{array}{l}10 \text { anak men- } \\
\text { jawab senang }\end{array}$ & $\begin{array}{l}\text { - Ceritanya } \\
\text { bagus } \\
\text { - Gaya ibu ber- } \\
\text { cerita lucu }\end{array}$ \\
\hline & & $\begin{array}{l}7 \text { anak menja- } \\
\text { wab biasa saja }\end{array}$ & $\begin{array}{l}\text { - Ceritanya } \\
\text { kurang menarik } \\
\text { - Gambarnya } \\
\text { tidak jelas }\end{array}$ \\
\hline \multirow[t]{3}{*}{2.} & $\begin{array}{l}\text { Apa judul cerita } \\
\text { yang anak ibu } \\
\text { suka? }\end{array}$ & $\begin{array}{l}7 \text { anak menja- } \\
\text { wab "Cica cecak } \\
\text { nakal" }\end{array}$ & $\begin{array}{l}\text { - } \text { Ceritanya } \\
\text { bagus } \\
\text { - Gambarnya } \\
\text { lucu } \\
\text { - Karena singa- } \\
\text { nya baik }\end{array}$ \\
\hline & & $\begin{array}{l}6 \text { anak menja- } \\
\text { wab bebek yang } \\
\text { suka berterima } \\
\text { kasih }\end{array}$ & $\begin{array}{l}\text { - Cerita bebek- } \\
\text { nya lucu } \\
\text { - Gambarnya } \\
\text { bagus } \\
\text { - Karena si } \\
\text { Kwek bebek } \\
\text { yang baik }\end{array}$ \\
\hline & & $\begin{array}{l}4 \text { anak men- } \\
\text { jawab Yumi yang } \\
\text { baik hati }\end{array}$ & $\begin{array}{l}\text { - Ceritanya } \\
\text { bagus } \\
\text { - Gambarnya } \\
\text { lucu }\end{array}$ \\
\hline \multirow[t]{2}{*}{3.} & $\begin{array}{l}\text { Siapakah tokoh } \\
\text { dalam cerita } \\
\text { dongeng tadi } \\
\text { yang anak ibu } \\
\text { suka? }\end{array}$ & $\begin{array}{l}11 \text { anak men- } \\
\text { jawab Bebek } \\
\text { yang bernama Si } \\
\text { Kwek }\end{array}$ & $\begin{array}{l}\text { - Dia bebek } \\
\text { yang baik } \\
\text { - Selalu ber- } \\
\text { terima kasih } \\
\text { - Gambar si } \\
\text { Kwek lucu }\end{array}$ \\
\hline & & $\begin{array}{l}6 \text { anak men- } \\
\text { jawab Singa dan } \\
\text { Sapi }\end{array}$ & $\begin{array}{l}\text { - Karena men- } \\
\text { jadi Singa baik }\end{array}$ \\
\hline \multirow[t]{2}{*}{4.} & $\begin{array}{l}\text { Apakah anak } \\
\text { ibu mau meniru } \\
\text { perilaku baik } \\
\text { dalam cerita } \\
\text { dongeng ibu? }\end{array}$ & $\begin{array}{l}12 \text { anak menja- } \\
\text { wab mau }\end{array}$ & $\begin{array}{l}\text { - Supaya punya } \\
\text { banyak teman } \\
\text { - Supaya disa- } \\
\text { yang semua } \\
\text { orang } \\
\end{array}$ \\
\hline & & $\begin{array}{l}5 \text { anak menja- } \\
\text { wab tidak tahu }\end{array}$ & $\begin{array}{l}\text { - Karena kurang } \\
\text { memahami } \\
\text { isi cerita do- } \\
\text { ngengnya. }\end{array}$ \\
\hline
\end{tabular}

Setelah melakukan Siklus II mulai dari pertemuan I dan pertemuan II, peneliti melakukan tanya jawab kepada anak tentang kegiatan yang telah dilakukan. Dari beberapa pertanyaan di atas, beberapa anak sudah dapat menjawab pertanyaan dengan baik serta bisa membedakan perbuatan baik dan buruk dalam cerita dongeng.

Hasil observasi kemampuan anak dalam meningkatkan perkembangan moral anak usia dini melalui mendongeng pada Siklus I pada pertemuan pertama 
dapat dilihat pada tabel 7 .

Tabel 7.

Hasil Observasi Sikap Perilaku dalam Meningkatkan Perkembangan Moral Anak Melalui Mendongeng Siklus I Pertemuan I (Setelah Tindakan)

$$
\begin{aligned}
& \mathrm{P}=\frac{\mathrm{F}}{\mathrm{N}} \times 100 \% \quad \mathrm{~N}=17
\end{aligned}
$$

\begin{tabular}{|l|l|c|c|c|c|c|c|}
\hline \multirow{2}{*}{ No. } & \multicolumn{2}{|c|}{ Aspek } & \multicolumn{2}{|c|}{$\begin{array}{c}\text { Nilai } \\
\text { Tinggi } \\
\text { (ST) }\end{array}$} & \multicolumn{2}{|c|}{$\begin{array}{c}\text { Tinggi } \\
\text { (T) }\end{array}$} & \multicolumn{2}{c|}{$\begin{array}{c}\text { Rendah } \\
\text { (R) }\end{array}$} \\
\cline { 3 - 8 } & $\begin{array}{c}\text { Jml } \\
\text { anak }\end{array}$ & $\%$ & $\begin{array}{c}\text { Jml } \\
\text { anak }\end{array}$ & $\%$ & $\begin{array}{c}\text { Jml } \\
\text { anak }\end{array}$ & $\%$ \\
\hline 1 & $\begin{array}{l}\text { Anak mau menga- } \\
\text { jak teman bermain } \\
\text { dan belajar }\end{array}$ & 3 & 17.6 & 5 & 29.41 & 9 & 52.94 \\
\hline 2 & $\begin{array}{l}\text { Anak senang } \\
\text { menolong }\end{array}$ & 4 & 23.52 & 6 & 35.29 & 7 & 41.17 \\
\hline 3 & $\begin{array}{l}\text { Anak mau memo- } \\
\text { hon dan memberi } \\
\text { maaf }\end{array}$ & 4 & 23.52 & 5 & 29.41 & 8 & 47.05 \\
\hline 4 & $\begin{array}{l}\text { Anak selalu } \\
\text { berterima kasih } \\
\text { jika memperoleh } \\
\text { sesuatu }\end{array}$ & 5 & 29.41 & 2 & 11.76 & 10 & 58.82 \\
\hline Nilai rata-rata & 4 & 23.52 & 4.5 & 26.46 & 8.5 & 49.99 \\
\hline
\end{tabular}

ST $($ Sangat Tinggi $)=$ Anak dapat memahami nasehat cerita. Dapat menerapkan nasehat dalam kehidupan

$\begin{aligned} \mathrm{T}(\text { Tinggi })= & \text { Anak dapat memahami nasehat } \\ & \text { dalam cerita tetapi masih mem- } \\ & \text { butuhkan arahan } \\ = & \text { Tidak dapat memahami nasehat } \\ \mathrm{R}(\text { Rendah }) \quad & \text { cerita }\end{aligned}$

Belum bisa menerapkan dalam kehidupan

Berdasarkan tabel di atas maka dapat dilihat sikap dan perilaku dalam meningkatkan perkembangan moral anak melalui mendongeng, Siklus I Pertemuan I pada aspek anak mau mengajak teman bermain dan belajar, ada 3 anak yang sangat tinggi nilainya dengan persentase $17.64 \%, 5$ anak memperoleh nilai tinggi dengan persentase $29.41 \%$, serta 9 anak memperoleh nilai rendah dengan persentase $52.94 \%$. Pada aspek anak senang menolong anak yang sangat tinggi, 4 orang dengan persentase $23.52 \%$, tinggi 6 orang dengan persentase $35.29 \%$, rendah 7 orang dengan persentase $41.17 \%$. Pada aspek dapat anak mau memohon dan memberi maaf anak yang sangat tinggi, 4 orang dengan persentase $25.52 \%$, anak yang tinggi 5 orang dengan persentase $29.41 \%$, rendah 8 orang dengan persentase $47.05 \%$. Pada aspek anak selalu berterima kasih jika memperoleh sesuatu anak yang sangat tinggi 5 orang dengan persentase $29.41 \%$, tinggi 2 orang dengan persentase $11.76 \%$, rendah 10 orang dengan persentase $58.82 \%$.

Dari uraian di atas tergambarlah sikap anak dalam mendengarkan cerita, pada siklus I pertemuan I sudah ada peningkatan tetapi belum maksimal, ini terlihat dalam 2 aspek sebagai berikut: antusias dalam mendengarkan cerita dan percaya diri mengulang kembali isi cerita, oleh karena itu perlu ditingkatkan lagi pada pertemuan berikutnya.

Hasil observasi sikap perilaku dalam meningkatkan perkembangan moral anak usia dini pada siklus I pertemuan II dapat dilihat pada tabel 8.

Tabel 8

Hasil Observasi Sikap Perilaku Dalam Meningkatkan Perkembangan Moral Anak Melalui Mendongeng Siklus I Pertemuan II (Setelah Tindakan)

$$
\mathrm{P}=\frac{\mathrm{F}}{\mathrm{N} \times 100 \%} \quad \mathrm{~N}=17
$$

\begin{tabular}{|l|l|c|c|c|c|c|c|}
\hline \multirow{2}{*}{ No. } & \multicolumn{2}{|c|}{ Aspek } & \multicolumn{2}{|c|}{$\begin{array}{c}\text { Sangat } \\
\text { Tinggi } \\
\text { (ST) }\end{array}$} & \multicolumn{2}{|c|}{$\begin{array}{c}\text { Tinggi } \\
\text { (T) }\end{array}$} & \multicolumn{2}{c|}{$\begin{array}{c}\text { Rendah } \\
\text { (R) }\end{array}$} \\
\cline { 2 - 8 } & $\begin{array}{c}\text { Jml } \\
\text { anak }\end{array}$ & $\%$ & $\begin{array}{c}\text { Jml } \\
\text { anak }\end{array}$ & $\%$ & $\begin{array}{c}\text { Jml } \\
\text { anak }\end{array}$ & $\%$ \\
\hline 1 & $\begin{array}{l}\text { Anak mau menga- } \\
\text { jak teman bermain } \\
\text { dan belajar }\end{array}$ & 6 & 35.29 & 4 & 23.52 & 7 & 41.17 \\
\hline 2 & $\begin{array}{l}\text { Anak senang } \\
\text { menolong }\end{array}$ & 8 & 47.05 & 4 & 23.52 & 5 & 29.41 \\
\hline 3 & $\begin{array}{l}\text { Anak mau memo- } \\
\text { hon dan memberi } \\
\text { maaf }\end{array}$ & 6 & 35.29 & 6 & 35.29 & 5 & 29.41 \\
\hline 4 & $\begin{array}{l}\text { Anak selalu } \\
\text { berterima kasih } \\
\text { jika memperoleh } \\
\text { sesuatu }\end{array}$ & 5 & 29.41 & 4 & 23.52 & 8 & 47.05 \\
\hline Nilai rata-rata & 6.25 & 36.76 & 4.5 & 26.46 & 6.25 & 36.76 \\
\hline
\end{tabular}

Berdasarkan tabel di atas maka dapat dilihat sikap dan perilaku dalam meningkatkan perkembangan moral anak melalui mendongeng Siklus I Pertemuan II pada aspek anak mau mengajak teman bermain dan belajar terdapat 6 anak yang memperoleh nilai sangat tinggi dengan persentase $35.29 \%$, 4 anak yang memperoleh nilai tinggi dengan persentase $23.52 \%$, serta 7 anak memperoleh nilai rendah dengan persentase $41.17 \%$. Pada aspek anak senang menolong terdapat 8 anak yang memperoleh nilai sangat tinggi dengan persentase $47.05 \%, 4$ anak memperoleh nilai tinggi dengan persentase $23.52 \%$, serta 5 anak 
memperoleh nilai rendah dengan persentase $29.41 \%$. Pada aspek dapat anak mau memohon dan memberi maaf, terdapat 6 anak memperoleh nilai sangat tinggi dengan persentase $35.29 \%, 6$ anak memperoleh nilai tinggi dengan persentase $35.29 \%$, serta 6 anak yang memperoleh nilai rendah dengan persentase $29.41 \%$. Pada aspek anak selalu berterima kasih jika memperoleh sesuatu, terdapat 5 anak yang memperoleh nilai sangat tinggi dengan persentase $29.41 \%, 4$ anak memperoleh nilai tinggi dengan persentase $23.52 \%$, serta 6 anak memperoleh nilai rendah dengan persentase $47.05 \%$.

Dari uraian di atas tergambarlah perkembangan moral anak pada siklus I pertemuan II sudah ada peningkatan tetapi belum maksimal. Ini terlihat dalam 4 aspek sebagai berikut: anak mau mengajak teman bermain dan belajar, anak senang menolong, anak mau memohon dan memberi maaf dan anak selalu berterima kasih jika memperoleh sesuatu. Sikap anak ketika mendengar cerita dongeng sangat rendah hal ini terlihat dari sikap anak yang masih kurang dan bersemangat dalam melakukan kegiatan.

Tabel 9

Hasil Observasi Sikap Anak Mendengarkan Cerita Dalam Meningkatkan Perkembangan Moral Anak Melalui Mendongeng Pada Siklus I Pertemuan II (Sesudah Tindakan)

$$
P=\frac{F}{N} \times 100 \% \quad N=17
$$

\begin{tabular}{|l|l|c|c|c|c|c|c|}
\hline \multirow{2}{*}{ No. } & \multicolumn{2}{|c|}{ Aspek } & \multicolumn{2}{|c|}{$\begin{array}{c}\text { Sangat } \\
\text { Tinggi } \\
\text { (ST) }\end{array}$} & \multicolumn{2}{c|}{$\begin{array}{c}\text { Tinggi } \\
\text { (T) }\end{array}$} & \multicolumn{2}{c|}{$\begin{array}{c}\text { Rendah } \\
\text { (R) }\end{array}$} \\
\cline { 3 - 8 } & $\begin{array}{c}\text { Jml } \\
\text { anak }\end{array}$ & $\%$ & $\begin{array}{c}\text { Jml } \\
\text { anak }\end{array}$ & $\%$ & $\begin{array}{c}\text { Jml } \\
\text { anak }\end{array}$ & $\%$ \\
\hline 1 & $\begin{array}{l}\text { Antusias dalam } \\
\text { mendengarkan } \\
\text { cerita dongeng }\end{array}$ & 9 & 52.94 & 5 & 29.41 & 3 & 17.64 \\
\hline 2 & $\begin{array}{l}\text { Percaya diri dalam } \\
\text { mengulang kem- } \\
\text { bali isi cerita }\end{array}$ & 8 & 47.05 & 5 & 29.41 & 4 & 23.52 \\
\hline Nilai rata-rata & 8.5 & 49.99 & 5 & 29.41 & 3.5 & 20.58 \\
\hline
\end{tabular}

ST $($ Sangat Tinggi $)=$ Anak dapat memahami nasehat cerita, dapat menerapkan nasehat dalam kehidupan

$\mathrm{T}($ Tinggi $) \quad=$ Anak dapat memahami nasehat dalam cerita tetapi masih membutuhkan arahan

$\mathrm{R}$ (Rendah) = Tidak dapat memahami nasehat cerita. Belum bisa menerapkan dalam kehidupan
Dari tabel di atas dapat dilihat sikap anak mendengarkan cerita dalam meningkatkan perkembangan moral anak melalui mendongeng siklus I pertemuan II pada aspek antusias dalam mendengarkan cerita, terdapat 6 anak yang memiliki antusias sangat tinggi dengan persentase $37.5 \%, 3$ anak yang memiliki antusias tinggi dengan persentase $18.75 \%$, serta 7 anak yang memiliki antusias rendah dengan persentase $43.75 \%$. Pada aspek percaya diri dalam mengulang kembali isi cerita, terdapat 6 anak yang memiliki percaya diri sangat tinggi dengan persentase $37.5 \%, 4$ anak yang memiliki percaya diri tinggi dengan persentase $25 \%$, serta 6 anak yang memiliki percaya diri rendah dengan persentase $37.5 \%$.

Dari uraian di atas tergambarlah sikap anak dalam mendengarkan cerita, pada siklus I pertemuan II sudah ada peningkatan tetapi belum maksimal, ini terlihat dalamdua aspek sebagai berikut antusias dalam mendengarkan cerita dan percaya diri mengulang kembali isi cerita, oleh karena itu perlu ditingkatkan lagi pada siklus berikutnya.

c. Refleksi

Pelaksanaan pembelajaran pada siklus I, berjalan sesuai dengan rencana. Berdasarkan hasil pengamatan peneliti dengan guru yang berkolaborasi bahwa dampak pembelajaran sudah cukap berhasil, ini terlihat dari:

1) Sikap positif anak mengikuti pembelajaran sudah ada peningkatan yaitu $14.7 \%$ pada kondisi awal setelah siklus I pertemuan I meningkat $29.40 \%$, pertemuan II meningkat $49.99 \%$. Sedangkan anak yang sikap positifnya rendah berkurang dari kondisi awal $55.88 \%$, pada siklus I pertemuan I berkurang menjadi $35.29 \%$, pertemuan II berkurang menjadi $20.58 \%$.

2) Perubahan terhadap sikap perilaku dalam meningkatkan perkembangan moral anak meningkat:

a) Pada aspek anak mau mengajak bermain dan belajar, anak yang sangat tinggi pada kondisi awal $11.76 \%$ setelah siklus I pertemuan I meningkat menjadi $17.64 \%$, pertemuan II $35.29 \%$.

b) Anak senang menolong pada kondisi awal anak yang sangat tinggi $17.64 \%$ setelah diadakan siklus I pertemuan I meningkat menjadi $23.52 \%$, pertemuan II 47.05 .

c) Anak mau memohon dan memberi maaf pada kondisi awal anak yang sangat tinggi $11.76 \%$. Setelah diadakan siklus I pertemuan I meningkat menjadi $23.52 \%$, pertemuan II meningkat menjadi $35.29 \%$.

d) Anak selalu berterima kasih jika memperoleh sesuatu pada kondisi awal anak yang sangat 
tinggi $11.76 \%$. setelah diadakan siklus I pertemuan I meningkat menjadi $29.41 \%$, pertemuan II $29.41 \%$.

3) Ditinjau dari aktivitas guru, pembelajaran pada siklus I sudah berjalan dengan baik ada pula hal-hal yang harus diperhatikan guru, yaitu:

a) Masih ada $47.05 \%$ anak yang perkembangan moralnya masih rendah dan masih ada $20.58 \%$ anak yang sikap positifnya masih rendah dalam mengikuti kegiatan mendongeng.

b) Anak yang perkembangan moralnya sangat tinggi baru mencapai $29.41 \%$ berarti belum mencapai target yang diharapkan yaitu $75 \%$.

c) Masih ada anak yang malas dan kurang tertarik dalam mendengarkan cerita dongeng.

d) Masih terdapat beberapa orang anak yang belum bisa menerapkan pesan cerita dalam kehidupan sehingga belum nampak perubahan sikap perilaku mereka.

Untuk mengatasi hal di atas dilakukan hal sebagai berikut:

a) Memotivasi dan membimbing yang sikap positifnya masih rendah dan sedang agar di siklus ke dua sikap positifnya lebih meningkat.

b) Mendampingi anak secara individual terutama bagi anak-anak yang perkembangan moralnya masih rendah dan belum bisa mengulang cerita dengan baik.

c) Merancang kegiatan dengan lebih menarik lagi, dengan teknik mendongeng yang lebih menarik minat anak serta menyajikan cerita yang lebih menarik lagi dengan media buku cerita dongeng bergambar yang sangat mereka suka.

\section{Deskripsi Siklus II}

Dari hasil pelaksanaan siklus I, ternyata tidak mencapai hasil maksimum. Maka penulis melanjutkan penelitian pada siklus II yang dilakukan sebanyak 2 kali pertemuan. Pertemuan pertama dilaksanakan pada Hari Selasa tanggal 20 September 2011, pertemuan kedua dilaksanakan pada hari Selasa tanggal 27 September 2011.

\section{a) Perencanaan Tindakan}

Perencanaan siklus II ini hampir sama dengan siklus I. Guru melaksanakan proses pembelajaran untuk meningkatkan perkembangan moral anak dengan membuat satuan kegiatan harian (SKH) yang telah direncanakan. Kompetensi dasar diambil dari pembentukan perilaku dan kemampuan berbahasa. Dari pembentukan perilaku, kompetensi dasarnya adalah anak mau melakukan ibadah, terbiasa mengikuti aturan dan dapat hidup bersih, mulai belajar membedakan benar dan salah serta terbiasa berperilaku terpuji. Hasil belajar dari kompetensi dasar ini adalah terbiasa berperilaku sopan santun dengan indikator selalu berterima kasih jika memperoleh sesuatu. Terbiasa menunjukan kepedulian dengan indikatornya adalah senang menolong, mau memohon dan memberi maaf serta mengajak teman bermain dan belajar.

Peneliti membuat rencana pembelajaran yang lebih menarik minat anak. Lebih mempelajari lagi teknik dan kiat mendongeng. Memilih dan menceritakan cerita dongeng yang lebih menarik dan lebih banyak mengandung pesan moral dan nasehat kepada anak serta menyiapkan buku-buku dongeng yang manarik minat anak-anak.

b) Tindakan

Proses pembelajaran pada siklus II ini dilakukan sebanyak 2 kali yaitu pertemuan pertama dilakukan pada hari Selasa tanggal 20 September 2011. Pertemuan kedua dilakukan pada hari Selasa tanggal 27 September 2011. Pada siklus ke II ini lebih baik dari pada siklus I, karena pada siklus ke II ini anak sudah banyak yang suka dengan cerita dongeng, bahkan mereka sudah tidak sabar untuk mendengar cerita yang baru. Perubahan terhadap sikap perilaku anak sudah banyak yang mengalami perubahan kearah yang lebih baik.

Pertemuan pertama dilakukan pada hari Selasa tanggal 20 September 2011. Peneliti melakukan mendongeng pada kegiatan inti pembelajaran di sekolah, hal ini berguna untuk memberikan penyegaran kepada anak di dalam proses belajar mengajar sebelum melakukan kegiatan dengan langkah-langkah sebagai berikut:

1. Sebelum mulai kegiatan, guru bercerita tentang macam-macam binatang.

2. Peneliti dan anak bermain teka-teki. Binatang apakah aku? Aku binatang berbadan besar, aku suka makan tebu, aku mempunyai gading, hidung sangat panjang. Anak-anak pun menjawab gajah.

3. Pada pertemuan kali ini peneliti mendongeng kan cerita dengan judul "Bleduk penyelamat hutan" dengan singkatan cerita sebagai berikut:

Bleduk adalah seekor anak gajah, yang pada pagi itu sedang tidur. Di hutan Bleduk mempunyai banyak teman ada burung pipit, bebek, tikus, kura-kura, dan monyet. Pada pagi itu badan Bleduk kurang sehat rasanya ingin bersin terus. Si pipit menyuruh Bleduk cepat pergi mandi agar badannya segar. Di tengah jalan, Bleduk bertemu dengan kura-kura, dan dia mengajak kura-kura mandi kesungai, tiba-tiba di tengah jalan hidung bleduk merasa gatal dan ia pun bersin dengan sangat kuat sehingga tubuh kura-kurapun terpental jauh dan kura-kura pun marah kepadanya. 
Setelah sampai di sungai, Bleduk menceritakan kejadian tersebut kepada si bebek. Tapi hidungnya terasa gatal lagi, dan ia pun bersin mengenai si bebek sehingga bulu bebek rontok dan bebekpun marah kepadanya.

Di tengah perjalanan, Bleduk bertemu dengan monyet Bleduk pun mengajak monyet main bersamanya tetapi hidungnya terasa gatal lagi dan ia pun bersin mengenai si monyet, monyet juga ikut marah kepada bleduk. Bleduk menjadi sedih karena semua temannya tidak mau berteman dengan dia lagi. Pada saat Bleduk tertidur di sebuah pohon yang rindang, tiba-tiba si tikus berlari sambil berteriak kebakaran. Bleduk pun terbangun dan melihat api yang sudah besar membakar hutan tempat tinggalnya.

Semua binatang lari menyelamatkan diri, tapi Bleduk mempunyai akal, ia mengambil air sungai melalui belalainya dan meniupkan air ke api yang bergejolak. Melihat keberanian Bleduk, binatang lain pun datang membantu. Akhirnya hutan bisa diselamatkan. Teman-teman Bleduk meminta maaf kepadanya dan mengucapkan terima kasih kepada Bleduk pemberani serta mau berteman dengan Bleduk lagi.

4. Setelah selesai mendongeng peneliti terlebih dahulu mengadakan tanya jawab dengan anak tentang dongeng yang telah diceritakan.

5. Setelah anak-anak dapat menjawab pertanyaan dari peneliti, maka peneliti menyuruh mereka mengulang cerita dengan bahasa mereka. Ratarata sudah hampir semua anak dapat mengulang cerita dengan baik

6. Pada saat peneliti ingin menyampaikan pesan moral kepada anak, peneliti meminta anak yang mengambil pesan moral dari dongeng tersebut. Anak pun dapat menjawabnya yaitu "Bleduk gajah yang baik dan mau menolong temannya, senang berteman dan dia juga pemberani mau meyelamatkan hutan dari kebakaran. Sehingga Bleduk jadi pahlawan bagi teman-temannya. Anak pun telah bisa memahami pesan moral yang ada dalam dongeng.

Pertemuan kedua dilakukan pada hari Selasa tangga 27 September 2011, pada pertemuan kali ini sebelum peneliti mulai mendongeng, anak-anak sendiri yang meminta untuk di bacakan dongeng lagi. Dalam hal ini keinginan anak dalam mendengarkan cerita telah meningkat dengan baik dan mereka pun lebih tenang dalam mendengarkan cerita dongeng. Berikut tahapan kegiatan pada pertemuan ke III siklus II ini:

1. Setelah peneliti bercerita tentang tema yaitu bumi (lautan) dan hewan-hewan yang hidup di laut, penelitipun akan mendongengkan sebuah cerita binatang laut yang mempunyai sifat yang baik hati.
2. Peneliti mengkondisikan anak dengan mengadakan teka-teki. Apakah aku?, aku adalah seekor binatang, kalau di goreng rasaku sangat enak, aku mempunyai sirip dan sisik, aku bisa berenang. Anak-anak menjawab ikan.

3. Peneliti mulai mendongeng dengan cara memperlihatkan buku dongeng yang berjudul " Rumah Baru buat Omang “. Dengan ringkasan cerita sebagai berikut:

Di dasar laut yang indah hidup seekor ikan yang bernama idut, idut mempunyai banyak teman karena dia ikan yang ramah, dan suka menolong. Pada suatu hari Idut mendengar suara menangis, setelah di temui ternyata itu suara seekor umang-umang yang bernama Omang. Omang kehilangan rumahnya atau yang biasa di sebut cangkang. Idut pun menghibur Omang dan berjanji akan mencarikan rumah untuknya.

Idut pun menemui temannya Itang si bintang laut dan Acil si cacing laut. Di tempat mereka Idut pun menemukan rumah kelomang yang kosong. Idut pun bahagia dan segera berenang dengan cepat ke tempat Omang. Pada saat tiba di tempat Omang, idut terkejut Omang tidak ada, yang ada hanya seekor gurita. Ketika Idut ingin pergi, terdengar suara minta tolong, rupanya Omang di himpit oleh si gurita. Idut pun berusaha untuk menolong Omang. la mendekati gurita dan gurita berusaha untuk mengejarnya. Namun Idut berenang dengan sangat cepat dan dapat mengelabui si Gurita. Setelah keadaan aman Idut pun kembali menemui Omang dan menunjukan rumah baru untuknya. Hati Omang pun sangat senang dan dia pun berterima kasih kepada Idut. Akhirnya Idut, Omang, Acil, dan Itang dapat bermain bersama lagi.

4. Setelah mendongeng cerita, peneliti melihat wajah yang senang dan semangat pada diri anak. Peneliti menyuruh anak untuk mengulang cerita dengan bahasa mereka. Anak pun sangat antusias maju ke depan dan sudah dapat mengulang cerita dengan baik.

5. Peneliti mengadakan tanya jawab bersama anak tentang isi cerita. Dari semua pertanyaan yang diajukan anak dapat menjawabnya dengan baik. Dari hal tersebut berarti perhatian anak sudah terfokus dalam mendengarkan cerita.

6. Peneliti menyuruh anak mengambil nasehat dari cerita dongeng tadi, anak pun dapat mengatakan pesan moral dari dongeng tersebut, kalau kita harus saling menolong, bermain dengan teman dan jangan jadi seperti gurita yang suka menggangu kawan. Jadilah seperti Idut yang baik, penolong, dan punya banyak teman. Dari hal tersebut berarti anak sudah dapat mengambil pesan dan nasehat 
dalam cerita, serta dapat membedakan perbuatan baik dan buruk.

\section{c. Pengamatan}

Pada akhir siklus II kegiatan mendongeng dalam meningkatkan perkembangan moral anak telah menunjukkan kemajuan yang berarti, peneliti dan teman yang berkolaborasi mendapatkan hasil dari setiap aspek terlihat peningkatannya, yaitu:

1. Anak semakin tertarik mendengar cerita dongeng.

2. Anak dapat memahami dengan baik pesan moral yang ada dalam cerita dongeng

3. Anak dapat menerapkan pesan moral tersebut dalam kehidupannya. Untuk lebih jelas dapat dilihat pada tabel catatan lapangan perubahan sikap anak di bawah anak.

Tabel 10. Catatan Lapangan Guru Siklus II

\begin{tabular}{|c|c|}
\hline Pertemuan I & Catatan Perubahan Sikap Perilaku Anak \\
\hline $\begin{array}{c}1 \\
\text { Kegiatan Awal } \\
\text { (Pre-teaching } \\
\text { activities) }\end{array}$ & $\begin{array}{l}\text { Pada catatan lapangan ini peneliti meng- } \\
\text { amati perubahan terhadap sikap perilaku } \\
\text { anak yang sudah mengalami peningkatan. } \\
\text { Seperti Nisa, Rahmi, dan Rika sudah mau } \\
\text { membantu ibu guru dalam menyiapkan } \\
\text { bahan yang akan digunakan dalam pem- } \\
\text { belajaran kali ini. }\end{array}$ \\
\hline $\begin{array}{c}2 \\
\text { Kegiatan Inti } \\
\text { (whilst-teaching } \\
\text { activites) }\end{array}$ & $\begin{array}{l}\text { Pada saat guru akan mulai mendongeng, } \\
\text { anak sudah terfokus untuk mendengarkan. } \\
\text { Guru mulai bernyanyi dan bertepuk gajah. } \\
\text { Anak sudah tertarik dan tidak sabar untuk } \\
\text { mendengar dongeng hari ini. Setelah selesai } \\
\text { mendongeng. Peneliti mengamati pada saat } \\
\text { jam makan anak, Rangga mau berbagi air } \\
\text { minum dengan Davin yang pada hari itu lupa } \\
\text { membawa air minum }\end{array}$ \\
\hline $\begin{array}{c}3 \\
\text { Kegiatan Penutup } \\
\text { (Post-teaching } \\
\text { activities) }\end{array}$ & $\begin{array}{l}\text { Anak sudah mulai bisa menerapkan pesan } \\
\text { moral dalam cerita. Pada saat akan pulang, } \\
\text { Arya kehilangan sepatunya. Teman-teman } \\
\text { yang lain, seperti Yuda, Dewi, Santi dan } \\
\text { Andi membantu mencarikan sepatu Arya. } \\
\text { Arya pun tidak lupa mengucapkan terima } \\
\text { kasih pada teman-temannya. }\end{array}$ \\
\hline Pertemuan II & Catatan Perubahan Sikap Perilaku Anak \\
\hline $\begin{array}{c}1 \\
\text { Kegiatan Awal } \\
\text { (Pre-teaching } \\
\text { activities) }\end{array}$ & $\begin{array}{l}\text { Pada saat melakukan cerita pagi bersama } \\
\text { anak, peneliti mengamati anak lebih ten- } \\
\text { ang dalam mendengarkan cerita ibu guru. } \\
\text { Antusias anak dalam mendengar cerita } \\
\text { sudah sangat bagus sebelum guru mulai } \\
\text { bercerita anak sudah duduk dengan baik } \\
\text { dan bertanya "cerita apa hari ini, Bu?". }\end{array}$ \\
\hline $\begin{array}{c}2 \\
\text { Kegiatan Inti } \\
\text { (whilst-teaching } \\
\text { activites) }\end{array}$ & $\begin{array}{l}\text { Guru mendongeng dengan menggunakan } \\
\text { buku dongeng. Anak dengan spontan } \\
\text { mengucapkan "buku dongengnya bagus". } \\
\text { Setelah selesai bercerita anak sudah bisa } \\
\text { memahami nasehat dalam cerita. Dewi, } \\
\text { Nisa, dan Rangga berkata kalau idut ikan } \\
\text { yang baik dan senang menolong teman. }\end{array}$ \\
\hline $\begin{array}{c}3 \\
\text { Kegiatan } \\
\text { Penutup } \\
\text { (Post-teaching } \\
\text { activities) }\end{array}$ & $\begin{array}{l}\text { Pada saat akan pulang, ada } 3 \text { anak yang } \\
\text { berkelahi pada jam istirahat. Guru menyu- } \\
\text { ruh mereka untuk saling memaafkan dan } \\
\text { anakpun mau memaafkan. Anak-anak } \\
\text { pulang dengan tenang tanpa mendorong } \\
\text { temannya. }\end{array}$ \\
\hline
\end{tabular}

Dari catatan lapangan tersebut terlihat bahwa hasil dari setiap aspek mengalami peningkatan dan telah terjadi perubahan sikap perilaku yang meningkat pada anak. Peneliti pun merasa puas terhadap perubahan sikap perilaku tersebut.

Setelah membuat catatan lapangan yang berkaitan dengan kegiatan awal, kegiatan inti, dan kegiatan akhir pada setiap pertemuan, maka peneliti melakukan tanya jawab kepada anak tentang kegiatan yang telah dilakukan. Ini dirangkum dalam beberapa pertanyaan yang akan diajukan kepada anak sebagai berikut.

Tabel 11. Lembar Wawancara Anak Pada Siklus II (Setelah Tindakan) Pertemuan III

\begin{tabular}{|c|c|c|c|}
\hline No & Pertanyaan & Jawaban & Alasan \\
\hline 1. & $\begin{array}{l}\text { Bagaimana } \\
\text { perasaan } \\
\text { anak-anak ibu } \\
\text { ketika mende- } \\
\text { ngar cerita } \\
\text { dongeng ibu } \\
\text { tadi? }\end{array}$ & $\begin{array}{l}17 \text { anak } \\
\text { menjawab } \\
\text { senang }\end{array}$ & $\begin{array}{l}\text { - Ceritanya bagus } \\
\text { - Gaya ibu ber- } \\
\text { cerita lucu } \\
\text { - Gambarnya } \\
\text { bagus }\end{array}$ \\
\hline \multirow[t]{2}{*}{2.} & $\begin{array}{l}\text { Apa judul ceri- } \\
\text { ta yang anak } \\
\text { ibu suka? }\end{array}$ & $\begin{array}{l}9 \text { anak } \\
\text { menjawab } \\
\text { "Bleduk } \\
\text { penyelamat } \\
\text { hutan" }\end{array}$ & $\begin{array}{l}\text { - Ceritanya bagus } \\
\text { - Gambarnya lucu } \\
\text { - Karena si } \\
\text { Bleduk sang } \\
\text { pemberani dan } \\
\text { baik }\end{array}$ \\
\hline & & $\begin{array}{l}8 \text { anak } \\
\text { menjawab } \\
\text { "Rumah } \\
\text { buat } \\
\text { omang" }\end{array}$ & $\begin{array}{l}\text { - Ceritanya bagus } \\
\text { - Buku ceritanya } \\
\text { bagus }\end{array}$ \\
\hline \multirow[t]{2}{*}{3.} & $\begin{array}{l}\text { Siapakah } \\
\text { tokoh dalam } \\
\text { cerita dongeng } \\
\text { tadi yang anak } \\
\text { ibu suka? }\end{array}$ & $\begin{array}{l}11 \text { anak } \\
\text { menjawab } \\
\text { bledug }\end{array}$ & $\begin{array}{l}\text { - Dia gajah yang } \\
\text { baik } \\
\text { - Selalu sabar, } \\
\text { menolong }\end{array}$ \\
\hline & & $\begin{array}{l}6 \text { anak } \\
\text { menjawab } \\
\text { Idut }\end{array}$ & $\begin{array}{l}\text { - Karena punya } \\
\text { banyak teman } \\
\text { - Suka menolong } \\
\text { - Ikan yang baik }\end{array}$ \\
\hline \multirow[t]{2}{*}{4.} & $\begin{array}{l}\text { Apakah anak } \\
\text { ibu mau me- } \\
\text { niru perilaku } \\
\text { baik dalam } \\
\text { cerita dongeng } \\
\text { ibu? }\end{array}$ & $\begin{array}{l}16 \text { anak } \\
\text { menjawab } \\
\text { mau }\end{array}$ & $\begin{array}{l}\text { - Supaya punya } \\
\text { banyak teman } \\
\text { - Supaya disa- } \\
\text { yang semua } \\
\text { orang } \\
\text { - Supaya jadi } \\
\text { anak yang baik }\end{array}$ \\
\hline & & $\begin{array}{l}1 \text { anak } \\
\text { hanya diam }\end{array}$ & $\begin{array}{l}\text { - Hanya diam dan } \\
\text { malu-malu }\end{array}$ \\
\hline
\end{tabular}


Dari hasil wawancara di atas dapat disimpulkan bahwa pemahaman anak tentang isi cerita dongeng meningkat, hal ini dapat dilihat anak-anak telah dapat menjawab pertanyaan yang diberikan dengan baik.

Untuk lebih jelasnya dapat dilihat pada tabel siklus II pertemuan I di bawah ini:

Tabel 12

Hasil Observasi Sikap Perilaku dalam Meningkatkan Perkembangan Moral Anak Melalui Mendongeng

Siklus II Pertemuan I

(Setelah Tindakan)

$P=\underline{F} \times 100 \%$

$\mathrm{N}$

\begin{tabular}{|l|l|c|c|c|c|c|c|}
\hline \multirow{2}{*}{ No. } & \multirow{2}{*}{ Aspek } & \multicolumn{2}{|c|}{$\begin{array}{c}\text { Nilai } \\
\text { Tinggi } \\
\text { (ST) }\end{array}$} & \multicolumn{2}{|c|}{$\begin{array}{c}\text { Tinggi } \\
\text { (T) }\end{array}$} & \multicolumn{2}{c|}{$\begin{array}{c}\text { Rendah } \\
\text { (R) }\end{array}$} \\
\cline { 2 - 8 } & $\begin{array}{c}\text { Jml } \\
\text { anak }\end{array}$ & $\%$ & $\begin{array}{c}\text { Jml } \\
\text { anak }\end{array}$ & $\%$ & $\begin{array}{c}\text { Jml } \\
\text { anak }\end{array}$ & $\%$ \\
\hline 1 & $\begin{array}{l}\text { Anak mau menga- } \\
\text { jak teman bermain } \\
\text { dan belajar }\end{array}$ & 7 & 41.17 & 6 & 35.26 & 4 & 23.52 \\
\hline 2 & $\begin{array}{l}\text { Anak senang } \\
\text { menolong }\end{array}$ & 10 & 58.82 & 5 & 29.41 & 2 & 11.76 \\
\hline 3 & $\begin{array}{l}\text { Anak mau memo- } \\
\text { hon dan memberi } \\
\text { maaf }\end{array}$ & 11 & 64.74 & 4 & 23.52 & 2 & 11.76 \\
\hline 4 & $\begin{array}{l}\text { Anak selalu } \\
\text { berterima kasin } \\
\text { jika memperoleh } \\
\text { sesuatu }\end{array}$ & 9 & 52.94 & 3 & 17.64 & 5 & 29.41 \\
\hline Nilai rata-rata & 9.25 & 54.41 & 4.5 & 26.45 & 3.25 & 19.11 \\
\hline
\end{tabular}

ST $($ Sangat Tinggi $)=$ Anak dapat memahami nasehat cerita. Dapat menerapkan nasehat dalam kehidupan

\section{$\mathrm{T}$ ( Tinggi $)=$ Anak dapat memahami nasehat dalam cerita tetapi masih mem- butuhkan arahan \\ $\mathrm{R}$ (Rendah) = Tidak dapat memahami nasehat cerita.Belum bisa menerapkan dalam kehidupan}

Berdasarkan tabel di atas, maka peningkatan terhadap perkembangan moral anak melalui mendongeng setelah siklus II pertemuan I pada aspek anak mau mengajak teman bemain dan belajar, terdapat 7 anak memperoleh nilai sangat tinggi dengan persentase $41.17 \%, 6$ anak memperoleh nilai tinggi dengan persentase $35.29 \%$, serta 4 anakmemperoleh nilai rendah dengan persentase $23.52 \%$. Pada aspek anak senang menolong, terdapat 10 anak memperoleh nilai sangat tinggi dengan persentase $58.82 \%, 5$ anak memperoleh nilai tinggi dengan persentase $29.41 \%$, serta 2 anak memperoleh nilai rendah dengan persentase $11.76 \%$. Pada aspek anak mau memohon dan memberi maaf, terdapat 11 anak memperoleh nilai sangat tinggi persentase $64.74 \%, 4$ anak memperoleh nilai tinggi dengan persentase $23.52 \%$, serta 2 anak memperoleh nilai rendah dengan persentase $11.76 \%$. Pada aspek anak berterima kasih jika memperoleh sesuatu, 9 anak memperoleh nilai sangat tinggi dengan persentase $52.94 \%, 3$ anak memperoleh nilai tinggi dengan persentase $17.64 \%$,serta 5 anak memperoleh nilai rendahdengan persentase $29.41 \%$.

Dari uraian di atas tergambarlah perkembangan moral anak pada siklus II pertemuan I sudah ada peningkatan tetapi belum maksimal. Ini terlihat dalam 4 aspek sebagai berikut: anak mau mengajak teman bermain dan belajar, anak senang menolong, anak mau memohon dan memberi maaf, serta anak selalu berterima kasih jika memperoleh sesuatu.

Sikap anak ketika mendengarkan cerita dapat dilihat pada tabel 13.

Tabel 13

Hasil Observasi Sikap Mendengarkan Cerita dalam Meningkatkan Perkembangan Moral Anak Melalui Mendongeng

Pada siklus II Pertemuan I (Sesudah Tindakan)

$$
P=\frac{F}{N} \times 100 \% \quad N=17
$$

\begin{tabular}{|l|l|c|c|c|c|c|c|}
\hline \multirow{2}{*}{ No. } & \multicolumn{1}{|c|}{ Aspek } & $\begin{array}{c}\text { Sangat } \\
\text { Tinggi } \\
\text { (ST) }\end{array}$ & \multicolumn{2}{c|}{$\begin{array}{c}\text { Tinggi } \\
\text { (T) }\end{array}$} & \multicolumn{2}{c|}{$\begin{array}{c}\text { Rendah } \\
\text { (R) }\end{array}$} \\
\cline { 3 - 8 } & $\begin{array}{c}\text { Jml } \\
\text { anak }\end{array}$ & $\%$ & $\begin{array}{c}\text { Jml } \\
\text { anak }\end{array}$ & $\%$ & $\begin{array}{c}\text { Jml } \\
\text { anak }\end{array}$ & $\%$ \\
\hline 1 & $\begin{array}{l}\text { Antusias dalam } \\
\text { mendengarkan } \\
\text { cerita dongeng }\end{array}$ & 11 & 64.74 & 4 & 23.52 & 2 & 11.76 \\
\hline 2 & $\begin{array}{l}\text { Percaya diri dalam } \\
\text { mengulang kem- } \\
\text { bali isi cerita }\end{array}$ & 12 & 70.58 & 2 & 11.76 & 3 & 17.64 \\
\hline Nilai rata-rata & 11.5 & 67.66 & 3 & 17.64 & 2.5 & 14.7 \\
\hline
\end{tabular}

ST $($ Sangat Tinggi $)=$ Anak dapat memahami nasehat cerita dan dapat menerapkan nasehat dalam kehidupan

$\mathrm{T}$ ( Tinggi $) \quad=$ Anak dapat memahami nasehat dalam cerita tetapi masih membutuhkan arahan

$\mathrm{R}$ (Rendah) = Tidak dapat memahami nasehat cerita dan belum bisa menerapkan dalam kehidupan

Dari tabel di atas terlihat bahwa sikap mendengarkan cerita dalam meningkatkan perkembangan moral anak melalui mendongeng setelah siklus II pertemuan I, pada aspek antusias dalam mendengar- 
kan cerita, terdapat 11 anak yang memiliki antusias sangat tinggi persentase $64.74 \%$, 4 anak yang memiliki antusias tinggi persentase $23.52 \%$, serta 2 anak yang memiliki antusias rendah dengan persentase $11.76 \%$. Pada aspek percaya diri dalam mengulang kembali isi cerita dongeng, terdapat 12 anak yang memiliki percaya diri sangat tinggi dengan persentase $70.58 \%, 2$ anak yang memiliki percaya diri tinggi dengan persentase $11.76 \%$, serta 3 anak yang memiliki percaya diri rendah dengan persentase $17.64 \%$.

Hasil observasi perkembangan motivasi membaca anak pada siklus II setelah tindakan pada pertemuan II dapat dilihat pada tabel 14

Tabel 14.

Hasil Observasi Sikap Perilaku Dalam Meningkatkan Perkembangan Moral Anak Melalui Mendongeng Siklus II Pertemuan II (Setelah Tindakan)

$$
\begin{aligned}
& P=E \times 100 \% \\
& \mathrm{~N}=17 \\
& \mathrm{~N}
\end{aligned}
$$

\begin{tabular}{|c|l|c|c|c|c|c|c|}
\hline \multirow{2}{*}{ No. } & \multicolumn{2}{|c|}{ Aspek } & \multicolumn{2}{|c|}{$\begin{array}{c}\text { Sangat } \\
\text { Tinggi } \\
\text { (ST) }\end{array}$} & \multicolumn{2}{|c|}{$\begin{array}{c}\text { Tinggi } \\
\text { (T) }\end{array}$} & \multicolumn{2}{c|}{$\begin{array}{c}\text { Rendah } \\
\text { (R) }\end{array}$} \\
\cline { 3 - 8 } & $\begin{array}{c}\text { Jml } \\
\text { anak }\end{array}$ & $\%$ & $\begin{array}{c}\text { Jml } \\
\text { anak }\end{array}$ & $\%$ & $\begin{array}{c}\text { Jml } \\
\text { anak }\end{array}$ & $\%$ \\
\hline 1 & $\begin{array}{l}\text { Anak mau } \\
\text { mengajak teman } \\
\text { bermain dan } \\
\text { belajar }\end{array}$ & 13 & 76.47 & 3 & 17.64 & 1 & 5.88 \\
\hline 2 & $\begin{array}{l}\text { Anak senang } \\
\text { menolong }\end{array}$ & 14 & 82.35 & 3 & 17.64 & - & - \\
\hline 3 & $\begin{array}{l}\text { Anak mau } \\
\text { memohon dan } \\
\text { memberi maaf }\end{array}$ & 15 & 88.23 & 2 & 11.76 & - & - \\
\hline 4 & $\begin{array}{l}\text { Anak selalu } \\
\text { berterima kasin } \\
\text { jika memperoleh } \\
\text { sesuatu }\end{array}$ & 11 & 64.74 & 4 & 23.52 & 2 & 11.76 \\
\hline Nilai rata-rata & 13.25 & 77.94 & 3 & 17.64 & 0.75 & 4.41 \\
\hline
\end{tabular}

ST $($ Sangat Tinggi $)=$ Anak dapat memahami nasehat cerita dan dapat menerapkan nasehat dalam kehidupan

\section{$\mathrm{T}$ ( Tinggi ) = Anak dapat memahami nasehat dalam cerita tetapi masih mem- butuhkan arahan \\ $\mathrm{R}$ (Rendah) = Tidak dapat memahami nasehat cerita dan belum bisa menerap- kan dalam kehidupan}

Berdasarkan tabel di atas, maka peningkatan terhadap perkembangan moral anak melalui mendongeng setelah siklus II pertemuan II pada aspek anak mau mengajak teman bemain dan belajar, terdapat 13 anak yang memperoleh nilai sangat tinggi dengan persentase $76.57 \%, 3$ anak memperoleh nilai tinggi dengan persentase $17.64 \%$, serta 1 anak memperoleh nilai rendah dengan persentase $5.88 \%$. Pada aspek anak senang menolong, terdapat 14 anak memperoleh nilai sangat tinggi dengan persentase $82.35 \%, 3$ anak memperoleh nilai tinggi dengan persentase $17.64 \%$, serta tidak ada anak yang meperoleh nilai rendah. Pada aspek anak mau memohon dan memberi maaf, terdapat 15 anak memperoleh nilai sangat tinggi dengan persentase $88.23 \%, 2$ anak memperoleh nilai tinggi dengan persentase $11.76 \%$, serta tidak ada anak yang memperoleh nilai rendah. Pada aspek anak berterima kasih jika memperoleh sesuatu, terdapat 11 anak memperoleh nilai sangat tinggi dengan persentase $64.74 \%, 4$ anak memperoleh nilai tinggi dengan persentase $23.52 \%$, serta 2 anak memperoleh nilai rendah dengan persentase $11.76 \%$.

Dari uraian di atas, tergambarlah perkembangan moral anak pada siklus II pertemuan III sudah terjadi peningkatan yang sangat signifikan. Ini terlihat dalam keempat aspek sebagai berikut: anak mau mengajak teman bermain dan belajar, anak senang menolong, anak mau memohon dan memberi maaf dan anak selalu berterima kasih jika memperoleh sesuatu sudah menunjukkan hasil maka penelitian tidak perlu lagi dilanjutkan. Sikap anak ketika mendengarkan cerita dapat dilihat pada tabel 15

\section{Tabel 15}

Hasil Observasi Sikap Mendengarkan Cerita dalam Meningkatkan Perkembangan Moral Anak Melalui Mendongeng Pada siklus II Pertemuan II (Sesudah Tindakan)

\begin{tabular}{|c|c|c|c|c|c|c|c|}
\hline \multirow{2}{*}{ No. } & \multirow{2}{*}{ Aspek } & \multicolumn{2}{|c|}{\begin{tabular}{c}
\multicolumn{2}{|c|}{ Nilai } \\
\cline { 3 - 7 } (ST)
\end{tabular}} & \multicolumn{2}{|c|}{$\begin{array}{c}\text { Tinggi } \\
\text { (T) }\end{array}$} & \multicolumn{2}{|c|}{$\begin{array}{c}\text { Rendah } \\
\text { (R) }\end{array}$} \\
\cline { 2 - 7 } & $\begin{array}{c}\text { Jml } \\
\text { anak }\end{array}$ & $\%$ & $\begin{array}{c}\text { Jml } \\
\text { anak }\end{array}$ & $\%$ & \multicolumn{2}{|c|}{$\begin{array}{c}\text { Jml } \\
\text { anak }\end{array}$} & $\%$ \\
\hline 1 & $\begin{array}{l}\text { Antusias } \\
\text { dalam } \\
\text { mende- } \\
\text { ngarkan } \\
\text { cerita } \\
\text { dongeng }\end{array}$ & 15 & 88.23 & 2 & 11.76 & - & - \\
\hline 2 & $\begin{array}{l}\text { Percaya } \\
\text { diri } \\
\text { dalam } \\
\text { mengu- } \\
\text { lang } \\
\text { kembali } \\
\text { isi cerita }\end{array}$ & 13 & 76.47 & 3 & 17.64 & 1 & 5.88 \\
\hline Nilai rata-rata & 14 & 82.35 & 2.5 & 14.7 & 0.5 & 2.94 \\
\hline
\end{tabular}

Dari tabel di atas terlihat bahwa sikap mendengarkan cerita dalam meningkatkan perkembangan moral anak melalui mendongeng setelah siklus II pertemuan II, pada aspek antusias dalam mendengarkan cerita, anak yang memiliki antusias sangat tinggi sebanyak 15 anak dengan persentase $88.23 \%$, anak 
yang memiliki antusias tinggi sebanyak 2 anak dengan persentase $11.76 \%$, serta tidak ada anak yang memiliki antusias rendah. Pada aspek percaya diri dalam mengulang kembali isi cerita dongeng, terdapat 13 anak yang memiliki percaya diri sangat tinggi dengan persentase $76.47 \%, 3$ anak memiliki percaya diri tinggi dengan persentase $17.64 \%$, serta 1 anak yang memiliki percaya diri rendah dengan persentase $5.88 \%$.

Dari uraian tabel di atas tergambarlah sikap anak dalam mendengarkan cerita dalam meningkatkan perkembangan moral anak, pada siklus II pertemuan II sudah menunjukan target pencapaian yang maksimal untuk itu peneliti tidak lagi melaksanakan penelitian pada siklus berikutnya.

4) Refleksi

Keberhasilan yang telah diperoleh pada siklus II dapat diuraikan sebagai berikut:

a) Sikap positif anak mengikuti pembelajaran mengalami peningkatan di setiap pertemuan I dan II pada siklus I sedangkan pada siklus II setiap pertemuan I dan II juga mengalami peningkatan

b) Perubahan terhadap sikap perilaku anak dalam meningkatkan perkembangan moral dalam kategori sangat tinggi meningkat yaitu anak mau mengajak teman bermain dan belajar, anak senang menolong, anak mau memohon dan memberi maaf, anak selalu berterima kasih jika memperoleh sesuatu.

c) Adanya upaya peneliti membuat perbaikan yang dilakukan pada pembelajaran pada siklus II menjadi lebih baik.

Berdasarkan hasil penelitian tersebut dan dari pencapaian hasil akhir siklus I dan II, peneliti berkeyakinan bahwa melalui mendongeng dengan cerita yang mendidik akan dapat meningkatkan perkembangan moral anak pada kelompok B1 di TK Dharmawanita UNP Padang.

Pembahasan mengenai hasil observasi meningkatkan perkembangan moral anak usia dini melalui mendongeng di TK Dharmawanita UNP Padang. Berdasarkan kondisi awal, sebagian besar anak kelompok BI belum memahami tentang perbuatan baik dan buruk yang sering mereka lakukan. Menurut pendapat beberapa para ahli bahwa karakteristik perkembangan moral anak usia dini dapat peneliti simpulkan seperti menurut pendapat Santrock (2007), perkembangan moral anak merupakan perubahan penalaran, perasaan, dan perilaku tentang standar mengenai benar dan salah dan bagaimana anak menerapkannya dalam kehidupan.

Dalam Kurikulum Berbasis Kompetensi (2004) mengatakan sikap perilaku baik pada diri anak ditandai dengan anak senang mengajak teman bermain dan belajar, anak senang menolong, anak mau memohon dan memberi maaf serta anak selalu berterima kasih jika memperoleh sesuatu. Karakteristik perkembangan moral anak usia dini melalui mendongeng, mampu dilakukan anak dengan baik, sehingga perkembangan moral anak meningkat sesuai dengan tujuan yang diharapkan. Keberhasilan meningkatkan perkembangan moral anak melalui mendongeng dapat dijabarkan sebagai berikut:

Berdasarkan tingkatan penelitian siklus I dan siklus II dapat dijabarkan keberhasilan meningkatkan perkembangan moral anak melalui mendongeng sebagai berikut:

1) Sikap positif anak dalam mengikuti kegiatan terjadi peningkatan, yaitu $14.7 \%$ pada kondisi awal, setelah diadakan siklus I meningkat menjadi $49.99 \%$, setelah diadakan siklus II meningkat menjadi $82.35 \%$. Sedangkan pada sikap positifnya rendah berkurang dari $55.88 \%$ pada kondisi awal, setelah diadakan siklus I berkurang menjadi $20.58 \%$, dan setelah siklus II berkurang menjadi $2.94 \%$

2) Ditinjau dari aktivitas guru, pembelajaran pada siklus II sudah berjalan dengan baik dan berhasil.

3) Perubahan sikap perilaku dalam meningkatkan perkembangan moral anak melalui mendongeng mengalami peningkatan sebagai berikut:

a) Dari aspek anak mau mengajak teman bermain dan belajar anak yang sikap perilakunya sangat tinggi pada kondisi awal $11.76 \%$, setelah diadakan siklus I meningkat menjadi $35.29 \%$, pada siklus II meningkat menjadi $76.47 \%$.

b) Dari aspek anak senang menolong, anak yang sangat tinggi pada kondisi awal $17.64 \%$, setelah diadakan siklus I meningkat menjadi $47.05 \%$, pada siklus II meningkat menjadi $82.35 \%$.

c) Dari aspek anak mau memohon dan memberi maaf, anak yang sangat tinggi pada kondisi awal $11.76 \%$, setelah diadakan siklus I meningkat menjadi $35.29 \%$, pada siklus II meningkat menjadi $88.23 \%$.

d) Dari aspek anak selalu berterima kasih jika memperoleh sesuatu anak sangat tinggi pada kondisi awal $11.76 \%$, setelah diadakan siklus I meningkat menjadi $29.41 \%$, pada siklus II meningkat naik menjadi $64.74 \%$.

Meningkatkan perkembangan moral anak usia dini melalui mendongeng di TK Dharmawanita UNP Padang terjadi peningkatan mulai dari kondisi awal, siklus I dan siklus II. Untuk lebih jelasnya tentang peningkatan perkembangan moral anak dapat dilihat pada tabel 16 . 
Tabel 16

Sikap Perilaku dalam Meningkatkan Perkembangan Moral Anak Melalui Mendongeng ( Anak Kategori Sangat Tinggi)

\begin{tabular}{|l|l|c|c|c|c|}
\hline No. & \multicolumn{1}{|c|}{ Aspek } & $\begin{array}{c}\text { Kondisi } \\
\text { Awal }\end{array}$ & Siklus I & Siklus II & Ket \\
\hline 1. & $\begin{array}{l}\text { Anak mau } \\
\text { mengajak teman } \\
\text { bermain dan } \\
\text { belajar }\end{array}$ & 11.76 & 35.29 & 76.47 & Naik \\
\hline 2. & $\begin{array}{l}\text { Anak senang } \\
\text { menolong }\end{array}$ & 11.76 & 47.05 & 80.35 & Naik \\
\hline 3. & $\begin{array}{l}\text { Anak mau } \\
\text { memohon dan } \\
\text { memberi maaf }\end{array}$ & 17.64 & 35.29 & 88.23 & Naik \\
\hline 4. & $\begin{array}{l}\text { Anak selalu } \\
\text { berterima kasih } \\
\text { jika memperoleh } \\
\text { sesuatu }\end{array}$ & 11.76 & 29.41 & 64.74 & Naik \\
\hline \multicolumn{2}{|l}{ Nilai rata-rata } & 13.23 & 36.76 & 77.44 & Naik \\
\hline
\end{tabular}

Berdasarkan tabel di atas, sikap perilaku dalam meningkatkan perkembangan moral anak dalam kategori sangat tinggi pada aspek anak mau mengajak teman bermain dan belajar, kondisi awal $11.76 \%$, pada siklus I naik menjadi $35.29 \%$, pada siklus II naik menjadi $76.47 \%$. Untuk aspek anak senang menolong kondisi awal $11.76 \%$, pada siklus I naik menjadi $47.05 \%$, pada siklus II naik menjadi $80.35 \%$. Untuk aspek anak mau memohon dan memberi maaf kondisi awal $17.74 \%$, pada siklus I naik menjadi $35.29 \%$, pada siklus II naik menjadi $88.23 \%$, pada aspek anak selalu berterima kasih jika memperoleh sesuatu kondisi awal $11.76 \%$, pada siklus I naik menjadi $29.41 \%$, pada siklus II naik menjadi $64.74 \%$.

Hasil observasi dalam mengembangkan motivasi membaca anak usia dini kategori tinggi nilai ratarata menurun dari kondisi awal $19.11 \%$, pada siklus I $26.46 \%$, pada siklus II menurun $17.64 \%$. Untuk lebih jelasnya dapat dilihat pada tabel 17

Tabel 17

Sikap Perilaku dalam Meningkatkan Perkembangan Moral Anak Melalui Mendongeng (Anak Kategori Tinggi)

\begin{tabular}{|c|c|c|c|c|c|}
\hline No. & Aspek & $\begin{array}{c}\text { Kondisi } \\
\text { Awal }\end{array}$ & Siklus I & Siklus II & Ket \\
\hline 1. & $\begin{array}{l}\text { Anak mau } \\
\text { mengajak } \\
\text { teman } \\
\text { bermain dan } \\
\text { belajar }\end{array}$ & 23.52 & 23.52 & 17.64 & Menurun \\
\hline 2. & $\begin{array}{l}\text { Anak } \\
\text { senang } \\
\text { menolong }\end{array}$ & 23.52 & 23.52 & 17.64 & Menurun \\
\hline
\end{tabular}

\begin{tabular}{|c|l|c|c|c|c|}
\hline No. & Aspek & $\begin{array}{c}\text { Kondisi } \\
\text { Awal }\end{array}$ & Siklus I & Siklus II & Ket \\
\hline 3. & $\begin{array}{l}\text { Anak mau } \\
\text { memohon } \\
\text { dan mem- } \\
\text { beri maaf }\end{array}$ & 17.64 & 35.29 & 11.76 & Menurun \\
\hline 4. & $\begin{array}{l}\text { Anak selalu } \\
\text { berterima } \\
\text { kasih jika } \\
\text { memperoleh } \\
\text { sesuatu }\end{array}$ & 11.76 & 23.52 & 23.52 & Menurun \\
\hline \multicolumn{2}{|c|}{ Nilai rata-rata } & 19.11 & 26.46 & 17.64 & Menurun \\
\hline
\end{tabular}

Sikap perilaku dalam meningkatkan perkembangan moral anak melalui mendongeng (anak kategori tinggi) berdasarkan tabel di atas dapat dilihat pada aspek anak mau mengajak teman bermain dan belajar kondisi awal $23.52 \%$, pada siklus I menjadi $23.52 \%$, pada siklus II menurun menjadi $17.64 \%$. Pada aspek anak mau menolong kondisi awal $23.52 \%$, pada siklus I menjadi $23.52 \%$, pada siklus II menurun menjadi $17.64 \%$. Pada aspek anak mau memohon dan memberi maaf kondisi awal $17.64 \%$, pada siklus I menjadi $35.29 \%$, pada siklus II menurun menjadi $11.76 \%$. Pada aspek anak selalu berterima kasih jika memperoleh sesuatu kondisi awal $11.76 \%$, pada siklus I menjadi $23.52 \%$, pada siklus II menjadi $23.52 \%$.

Dari hasil uraian tabel di atas tergambarlah sikap anak dalam meningkatkan perkembangan moral pada anak. Dapat terlihat pada kondisi awal, siklus I dan siklus II pada kategori tinggi mengalami penurunan.

Hasil observasi dalam meningkatkan perkembangan moral anak usia dini kategori rendah nilai ratarata menurun dari kondisi awal $67.65 \%$, pada siklus I $36.76 \%$, pada siklus II menurun $4.41 \%$.

Tabel 18

Sikap Perilaku dalam Meningkatkan Perkembangan Moral Anak Melalui Mendongeng (Anak Kategori Rendah)

\begin{tabular}{|l|l|c|c|c|l|}
\hline No. & \multicolumn{1}{|c|}{ Aspek } & $\begin{array}{c}\text { Kondisi } \\
\text { Awal }\end{array}$ & $\begin{array}{c}\text { Siklus } \\
\text { I }\end{array}$ & $\begin{array}{c}\text { Siklus } \\
\text { II }\end{array}$ & Ket \\
\hline 1. & $\begin{array}{l}\text { Anak mau } \\
\text { mengajak teman } \\
\text { bermain dan } \\
\text { belajar }\end{array}$ & 64.74 & 41.17 & 5.88 & Menurun \\
\hline 2. & $\begin{array}{l}\text { Anak senang } \\
\text { menolong }\end{array}$ & 58.82 & 29.41 & - & Menurun \\
\hline 3. & $\begin{array}{l}\text { Anak mau } \\
\text { memohon dan } \\
\text { memberi maaf }\end{array}$ & 70.58 & 29.41 & - & Menurun \\
\hline 4. & $\begin{array}{l}\text { Anak selalu } \\
\text { berterima kasih } \\
\text { jika memperoleh } \\
\text { sesuatu }\end{array}$ & 76.47 & 47.05 & 11.76 & Menurun \\
\hline & Nilai rata-rata & 67.65 & 36.76 & 4.41 & Menurun \\
\hline
\end{tabular}


Dari tabel di atas dapat dilihat sikap perilaku dalam meningkatkan perkembangan moral anak (anak kategori rendah) pada aspek anak dapat mengajak teman bermain dan belajar kondisi awal $64.74 \%$, pada siklus I menurun menjadi $41.17 \%$, pada siklus II menurun menjadi $5.88 \%$. Pada aspek anak senang menolong kondisi awal $58.82 \%$, pada siklus I menurun menjadi $29.41 \%$, pada siklus II menurun menjadi tidak ada. Pada aspek anak mau memohon dan memberi maaf kondisi awal $70.58 \%$, pada siklus I menurun menjadi $29.41 \%$, pada siklus II menurun menjadi tidak ada. Pada aspek anak selalu berterima kasih jika memperoleh sesuatu kondisi awal $76.47 \%$, pada siklus I menurun menjadi $47.05 \%$ dan pada siklus II menurun menjadi $11.76 \%$.

Dari hasil uraian di atas tergambarlah sikap perilaku anak dalam meningkatkan perkembangan moral anak. Dapat terlihat pada kondisi awal masih banyak anak yang belum memahami baik buruk dari perbuatan yang mereka lakukan. Dari permasalahan tersebut dilakukanlah tindakan untuk mengubah sikap perilaku anak ke arah yang lebih baik melalui kegiatan mendongeng yang berisikan pesan moral yang mendidik. Keberhasilan yang di capai pada siklus II ini jauh lebih baik untuk itu peneliti tidak melanjutkan pada siklus berikutnya.

\section{PENUTUP}

\section{Kesimpulan}

Berdasarkan hasil penelitian dan pembahasan yang dibahas di atas, maka dapat diambil kesimpulan sebagai berikut:

Pertama, TK merupakan Pendidikan Anak Usia Dini berumur 5-6 tahun, yang merupakan masa yang tepat untuk meletakkan dasar-dasar pengembangan pembiasaan salah satunya perkembangan moral.

Kedua, pada hakikatnya pendidikan anak usia dini adalah pemberian upaya untuk menstimulasi, membimbing, mengasuh dan menyediakan kegiatan pembelajaran yang dilakukan dengan cara yang menyenangkan. Untuk itu pendidikan anak usia dini adalah upaya untuk memfasilitasi pertumbuhan dan perkembangan anak.

Ketiga, salah satu cara untuk meningkatkan perilaku moral anak usia dini adalah melalui mendongeng yang berisi pesan moral.

Keempat, pengaruh lingkungan dan keluarga adalah hal yang paling penting dalam meningkatkan perkembangan moral anak.

Kelima, peran orang dan guru adalah hal yang paling utama memberikan pengasuhan yang positif, merespon dan mengarahkan setiap perilaku ke arah yang baik.

Keenam, tujuan untuk meningkatkan perkembangan moral anak melalui mendongeng adalah untuk mengenalkan kepada anak mana perbuatan baik dan mana perbuatan buruk serta memotivasi anak untuk terbiasa berperilaku baik.

Ketujuh, untuk menjadi seorang pendongeng yang hebat dan dapat menghidupkan suasana cerita, guru harus pandai dalam memilih cerita dan dapat menguasai teknik-teknik mendongeng.

Kedelapan, penyediaan buku-buku dongeng yang mendidik dan menarik akan dapat menimbulkan minat anak dalam mendengarkan cerita dongeng bagi pembentukan moralnya.

Kesembilan, sikap positif anak-anak di lokal B di TK Ananda dapat ditingkatkan melalui kegiatan mendongeng.

Kesepuluh, melalui kegiatan mendongeng dapat meningkatkan perkembangan moral anak, ini dapat di lihat dari peningkatan perkembangan moral anak dari kondisi awal ke siklus I ke siklus II yaitu pada siklus I nilai rata-rata yang terdapat pada anak yang sangat tinggi pada kondisi awal dengan persentase $14.06 \%$, siklus I $53.12 \%$ dan pada siklus II meningkat dengan persentase $85.93 \%$.

Pada umumnya anak dalam usia dini sangat suka bermain dengan teman sebayanya, anak juga dapat merasakan kesusahan teman sehingga timbulah sifat empati dari dirinya terhadap orang lain. Untuk itulah dibutuhkan bimbingan dan arahan sejak usia dini agar perilaku baik ini tetap tertanam hingga mereka dewasa.

Kita dapat membimbing dan mengarahkan sikap perilaku yang baik pada diri mereka dengan memberikan nasehat melalui cara yang menyenangkan sehingga mereka tidak terpaksa dan merasa digurui. Hal ini dapat dilakukan dengan bercerita atau mendongeng.

Dengan adanya penelitian tindakan kelas ini imbasnya terhadap guru adalah dapat memberikan wawasan, keterampilan serta ilmu pengetahuan dalam mengarahkan dan membimbing perkembangan moral anak ke arah yang lebih baik. Sedangkan imbasnya untuk anak kelompok B1 TK Dharmawanita UNP Padang dapat meningkatkan perkembangan moral mereka ke arah yang lebih baik.

\section{Saran}

Beberapa saran yang diberikan oleh penulis 
yang meliputi (1) agar pembelajaran lebih kondusif dan menarik minat anak, sebaiknya guru lebih kreatif dalam merancang kegiatan pembelajaran dengan dalam bentuk kegiatan yang menyenangkan; (2) pihak sekolah sebaiknya menyediakan buku-buku cerita dongeng yang menarik bagi anak serta mengandung pesan moral; (3) hendaknya guru mampu menguasai teknik-teknik mendongeng ini supaya cerita yang kita sampaikan lebih diminati lagi oleh anak; (4) jadikanlah kegiatan mendongeng sebagai salah satu cara dalam memberikan penanaman moral kepada anak di sekolah tanpa mereka merasa di gurui; (5) bagi peneliti lanjutan diharapkan dapat melanjutkan penelitian tentang kegiatan mendongeng; (6) bagi pembaca diharapkan dapat menggunakan penelitian ini sebagai sumber ilmu pengetahuan guna menambah wawasan.

\section{DAFTAR PUSTAKA}

Arikunto, S. (2006). Penelitian tindakan kelas. Jakarta: Bumi Aksara.

Agus, D.S. (2008). Mendongeng bareng KakAgus D.S yuk. Yogyakarta: Kanisius.

Agus, D.S. (2009). Tips jitu mendongeng. Yogyakarta: Kanisius.

Anwar \& Ahmad, A. (2007). Pendidikan anak usia dini. Bandung: Alfabeta.

Aziz, Abdul \& Majid, Abdul. (2003). Mendidik anak lewat cerita. Jakarta: Mustaqiim.

Bentri, Alwen, dkk. (2005). Usulan penelitian untuk peningkatan kwalitas pembelajaran. Padang: LPTK UNP.

Darmansyah. (2009). Penelitian tindakan kelas. Padang: Suka Bina Press.

Depdiknas. (2007). Jurnal IImiah Visi PTK-PNF. Jakarta: Depdiknas.

Depdiknas. (2008). Buku panduan penulisan tugas akhir atau skripsi. Padang: UNP.

Gay R.L, Air Peter Asian. Educational research. New Jersey: Merril.

Gichara, J. (2006). Mengatasi perilaku buruk anak. Jakarta: PT Kawan Pustaka.

Haryadi.(2009). Statistik pendidikan. Jakarta: Prestasi Pustaka Raya.

Hermansyah, dkk. (2000). Metode pengembangan agama, moral, disiplin dan afeksi. Bandung: Depdiknas
Hurlock, E. B. (1978). Perkembangan anak (Jilid 2). Jakarta: Erlangga.

Moeslichatoen. (1999). Metode pengajaran di TK. Jakarta: PT Kineka Cipta.

Musfiroh, T. (2005). Bercerita untuk anak usia dini. Jakarta: Depdiknas.

Ndraha, R. (2009). Mendisiplinkan lingkungan alam sekitar sebagai sumber belajar anak usia dini. Yogyakarta: IKAPI.

Nur'aini, F. (2007). Ma... Dongengin Aku Yuk!. Surakarta: Alfra Publishing.

Priyono, K. (2006). Terampil mendongeng. Jakarta: PT Grasindo.

Priyono, K. (2006). Mendongeng itu perlu. Tangerang: Lembaga Pelestarian dan Pengembangan Dongeng Indonesia.

Santrock, J.W. (2007). Perkembangan anak (Jilid 2). Jakarta: Erlangga.

Sayuti, S. (2008). Kiat asyik mendongeng. Yogyakarta: Arti Bumi Intaran.

Sjarkawi. (2006). Pembentukan kepribadian anak. Jakarta: PT Bumi Aksara

Sutrisno \& Hary, S.H. (2005). Pengenalan lingkungan alam sekitar sebagai sumber belajar anak usia dini. Jakarta: PT Grasindo.

UU RI No 20 tahun 2003. Tentang pendidikan nasional. Jakarta: Depdiknas.

Yudha, A. (2007). Cara pintar mendongeng. Bandung: Mizan. 